UDK 81'374.73'28:81.373.7

DOI https://dx.doi.org/10.21857/yvjrdclxey

Izvorni znanstveni članak

Rukopis primljen 28. IX. 2020.

Prihvaćen za tisak 8. II. 2021.

Martina Bašić

Zavod za lingvistička istraživanja

Hrvatska akademija znanosti i umjetnosti

Ulica književnika Ante Kovačića 5, HR-10000 Zagreb

mkovacev@hazu.hr

\title{
PUNE RUKE POSLA - \\ FRAZEMI SA SOMATSKOM SASTAVNICOM RUKA U RJEČNICIMA IZVORNIH ČAKAVSKIH GOVORA
}

$\mathrm{U}_{\text {radu}}{ }^{*}$ se na temelju ovjere u objavljenim rječnicima izvornih čakavskih govora izrađuje rječnička frazeološka nadnatuknica RUKA. Na temelju korpusa od 173 frazemske natuknice potvrđena je visoka produktivnost i predvidivost značenja frazema sa sastavnicom ruka u organskim govorima čakavskoga narječja.

\section{Uvod}

Dijalektološka su istraživanja svih triju hrvatskih narječja temeljna zadaća Zavoda za lingvistička istraživanja HAZU od njegova osnutka 1984. godine. Jedan od prvih projekata Zavoda za lingvistička istraživanja HAZU bio je projekt Rječnik čakavskoga narječja, voditelja akademika Milana Moguša. Rječnik čakavskoga narječja zamišljen je kao djelo u kojem bi bio zabilježen temeljni čakavski leksik s cjelokupnoga čakavskog terena, a gdje bi se sve varijante određenoga izraza za određeni sadržaj predočile pod jednom nadnatuknicom, tj. arhileksemom (Moguš 1985). Suradnici dugogodišnjega velikog zavodskog projekta Istraživanje hrvatskih dijalekata, kojeg je projekt Čakavskoga rječnika tijekom godina postao dijelom, objavili su niz radova u kojima su analizirali strukture postojećih rječnika mjesnih govora koji su trebali poslužiti kao izvori za Rječnik čakav-

* Rad je posvećen akademiku Goranu Filipiju, mojem dragom mlađem informantu... 
skoga narječja (npr. Vulić-Vranković 1997; Vulić-Vranković 1999) ili su davali smjernice za izradbu dijelova natukničkoga članka (Vulić-Vranković 2003). »Renesansa čakavske leksikografije « (Lisac 2018:160) koja se dogodila devedesetih godina prošloga stoljeća omogućila je da se od početnih, brojem skromnih, rječnika i popisa riječi izvornih čakavskih govora dođe do stotinjak izvora koji su poslužili za dio Rječnika čakavskoga narječja, tematsku cjelinu Dijelovi ljudskoga tijela (u rukopisu). Iz tih su izvora ispisane sve somatske natuknice i njihovi oblici s pripadajućom frazeološkom građom po načelima opisanima u Moguš 1985 i Vulić-Vranković 2003.

Ispisivanje je temeljnoga čakavskog leksika odgođeno dok se ne pronađe način (i sredstva) da se rječnički izvori digitaliziraju i dok se ne uspostavi javno dostupan digitalni repozitorij dijalektoloških leksikografskih sadržaja. Ta se leksikografska digitalizacija, za morfološki bogate govore kao što su hrvatski čakavski govori, ne bi trebala zaustaviti samo na pretraživim digitalnim formatima dokumenata nego je potrebno pronaći način da se dobiju strukturirani podatci obogaćeni metapodatcima što obuhvaća i izgradnju leksikona koji bi iscrpno obuhvaćao sve kombinacije morfema prema pravilima svih čakavskih govora.

Ipak, rad se na sintetskim prikazima širega čakavskog govornog područja nastavlja i danas pod okriljem projekta Istraživanje hrvatskih dijalekata i povijesti hrvatskoga jezika, ali na "suženom" području - na području čakavske frazeologije. Cilj je tih istraživanja potvrditi i donijeti nove zaključke o rasprostranjenosti hrvatske čakavske frazeološke građe, utvrditi veze i moguće utjecaje unutar skupina govora, poddijalekata i dijalekta, ali i utjecaje hrvatskoga standardnog jezika. Čvrsta veza sastavnica frazema i njihovo oblikovanje u organskom idiomu omogućit će dijalektolozima proučavanje osnovnih jezičnih značajki organskih govora u kojima se oni javljaju, ali i sastavnica frazema koje možda više nisu dio svakodnevnoga organskog govora. Stoga je u ovoj vrsti istraživanja žarište interesa ne samo na postojanju frazema u određenom govoru (kao što je bilo u Rječniku čakavskoga govora - dijelovi ljudskoga tijela) nego i na oprimjerenju frazema što će pokazati pravu sliku konkretnoga govora i frazema u njemu.

U ovome će radu, na temelju ovjere u objavljenim rječnicima izvornih čakavskih govora, biti prikazani frazemi sa somatskom sastavnicom ruka. Karta 1. prikazuje geografski razmještaj čakavskih mjesnih govora iz čijih su rječnika ekscerpirani frazemi. 
Martina Bašić: Pune ruke posla - frazemi sa somatskom sastavnicom ruka u rječnicima...

FILOLOGIJA 75(2020), 67-97

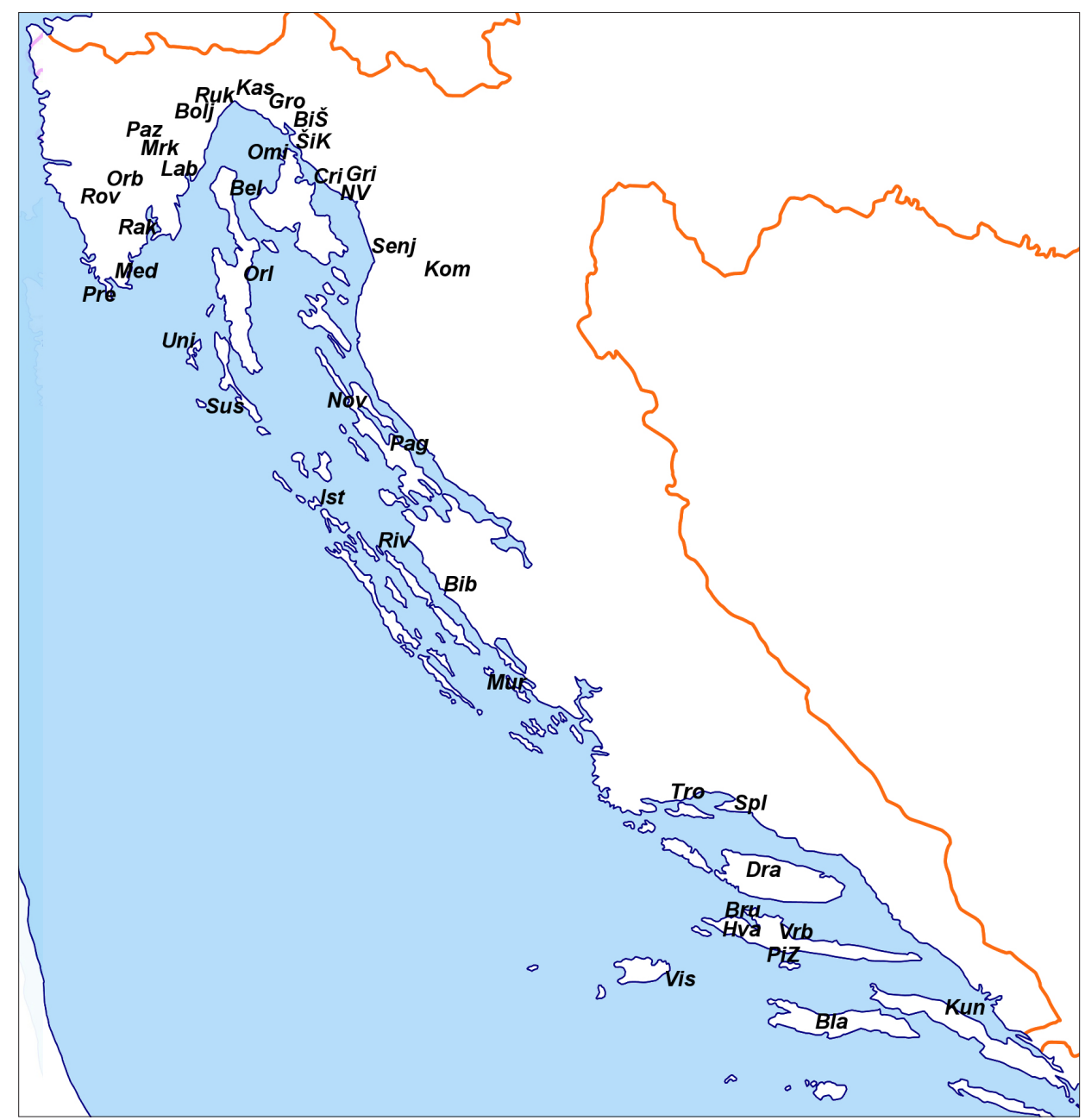

Karta 1. Geografski razmještaj čakavskih mjesnih govora

iz čijih su rječnika ekscerpirani frazemi sa somatskom sastavnicom ruka

Kratice govora

Bel - Beli; Bib - Bibinje; BiŠ - Bakarac i Škrljevo; Bla - Blato; Bolj - Boljun; Bru - Brusje; Cri - Crikvenica; Dra - Dračevica; Gri - Grižane; Gro Grobnik; Hva - Hvar; Ist - Ist; Kas - Kastav; Kon - Kompolje; Kun - Kuna; Lab - Labin; Med - Medulin; Mrk - Mrkoči; Mur - Murter; Nov - Novalja; NV - Novi Vinodolski; Omi - Omišalj; Orb - Orbanići; Orl - Orlec; Pag Pag; Paz - Pazin; PiZ - Pitve i Zavala; Pre - Premantura; Rak - Rakalj; Riv Rivanj; Rov - Roverija; Ruk - Rukavac; Senj - Senj; Spl - Split; Sus - Susak; ŠiK - Śmrika i Kraljevica; Tro - Trogir; Uni - Unije; Vis - Vis; Vrb - Vrboska 
Kako somatizmi pripadaju najstarijem sloju leksičkoga sustava i dio su temeljnoga leksika svakoga govora (somatski su frazemi vrlo brojni u svim frazeološkim korpusima), ${ }_{1}^{1}$ pretpostavlja se da će ekscerpirani frazemi sa somatskom sastavnicom ruka potvrditi dosadašnja istraživanja o visokoj produktivnosti tē somatske sastavnice. ${ }^{2}$ Također, pretpostavlja se da će značenje frazema sa somatskom sastavnicom biti predvidivo »jer ljudi imaju iste konvencionalne slike i konvencionalno znanje o dijelovima svojega tijela (Kovačević 2012:15) te da se frazemi potvrđeni u rječnicima izvornih čakavskih govora neće u većoj mjeri razlikovati od frazema drugih dvaju hrvatskih narječja i od standardnih frazema hrvatskoga jezika - osim, naravno, na planu izraza. Cilj je ovoga istraživanja potvrditi viso$\mathrm{ku}$ produktivnost i predvidivost značenja frazema sa sastavnicom ruka u organskim govorima čakavskoga narječja izradom rječničke nadnatuknice RUKA, ali i opisati leksikografske poteškoće na koje se nailazi pri izradi (samo jedne) frazemske natuknice na temelju već objavljene građe.

\section{Načela uspostave korpusa frazema sa somatskom sastavnicom ruka}

O prezentaciji frazeološke građe i zastupljenosti frazeologije u rječnicima čakavskih govora pisano je u Bogović 1997, Vulić Vranković 1997, Menac-Mihalić 1998, Vulić Vranković 1999 te Vulić Vranković 2003. U svim je člancima istaknuto kako frazeologija u čakavskim dijalektnim rječnicima nije sustavno (ili je samo djelomično sustavno) leksikografski prezentirana. Predloške za sustavnu prezentaciju frazema u budućim rječnicima izvornih čakavskih govora ponudile su Bogović (1997:130) i Vulić (1997:119). U razdoblju od posljednjega analitičkog članka iz 2003. godine do danas, objavljeno je četrdesetak novih čakavskih rječnika. U dijelu tih četrdesetak rječnika autori su sustavno, po frazeografskim "uputama”, prezentirali prikupljenu frazeološku građu (npr. Lukežić-Zubčić 2007, Ivančić-Dusper-Bašić 2013, Vranić-Oštarić 2016, Peruško 2018, Miletić 2019...), dok je u dijelu objavljenih rječnika frazeološka građa nepostojeća ili je (još uvijek) nesustavno prezentirana.

Ovom radu jedan od ciljeva nije analiza prezentacije frazeološke građe u postojećim objavljenim čakavskim rječnicima. No, određene će se poteš-

1 »Somatski frazemi vrlo su brojni u svim jezicima te prema podacima istraživanja R. M. Vajntrauba čine približno 30\% (Vajntraub 1975:162) svih frazema bilo kojeg jezika« (Dugandžić 2019:31).

2 U hrvatskoj somatskoj frazeologiji ruka je, uz glavu, jedna od najproduktivnijih somatskih sastavnica (Kovačević 2012:283). 
koće pri uspostavi frazemskih natuknica sa somatskom sastavnicom ruka, vezane za prezentaciju frazeološke građe u proučavanim rječnicima, prikazati u sljedećem poglavlju.

Za potrebe ovoga rada pregledana su 74 rječnika izvornih čakavskih govora, ${ }^{3}$ a za korpus frazeološke građe ekscerpirani su i frazemi iz jednoga diplomskog dijalektološko-frazeološkog rada. Frazemi sa somatskom sastavnicom ruka pronađeni su u 39 rječnika - što uključuje desetak rječnika u kojima su se pronašla samo dva-tri frazema. Možemo pretpostaviti da je najveći razlog neujednačenoj distribuciji frazema to što je primarni cilj pri izradi dijalektnih rječnika da se popiše leksik, a frazeologija je uvijek sekundarni cilj.

Iako dijalektolozi najčešće ne uzimaju u obzir građu koja nije naglašena, $\mathrm{u}$ istraživani su korpus, kako bi se dodatno prikazala regionalna raslojenost frazema, uključeni i frazemi iz izvora čija oprimjerenja nisu naglašena (npr. rječnik mjesnoga govora Ista ili rječnik mjesnih govora Šmrike i Kraljevice) ili su djelomično naglašena (npr. rječnik mjesnoga govora Rukavca). Potrebno je napomenuti da je u nekim, pretežno amaterskim, rječnicima uočena nedovoljno stručna i neusustavljena rječnička obradba ponajprije $u$ akcentuaciji i bilježenju akcenata. Tē su akcenatske nedosljednosti u primjerima frazema ispisanih za potrebe ovoga rada, $u$ onih kod kojih se to moglo, uklonjene. ${ }^{4}$

3 Među pregledanim rječnicima izvornih čakavskih govora našli su se i rječnici mjesnih govora koje danas odlikuju brojne štokavske značajke, kao npr. Splitski rječnik ili Kunovske stare riči (rječnik koji bilježi leksik mjesta Kuna na poluotoku Pelješcu). Na Dijalektološkoj karti čakavskoga narječja (Lisac 2009:188) punktovi Split i Kuna označeni su čakavskim govorima koji pripadaju južnočakavskom dijalektu.

4 U viškom je rječniku kratkosilazni naglasak bilježen znakom koji se u tradicionalnom znakovlju u hrvatskoj dijalektologiji upotrebljava za kratkouzlazni naglasak. U korpusu frazema ovoga rada u viškim je primjerima napravljena zamjena ' > ".

U omišaljskom rječniku upotrijebljena su samo dva znaka - znakovi za kratkosilazni i dugosilazni naglasak. Riječ je o govoru starijega akcenatskog inventara s očuvanim prednaglasnim i zanaglasnim duljinama. No, u rječniku su znakom za dugosilazni naglasak bilježene i duljine. Dok se riječi s kratkosilaznim naglaskom i s prednaglasnom ili zanaglasnom duljinom mogu "odgonetnuti", pronalaženje mjesta naglaska otežano je u primjerima riječi koje imaju dugosilazni naglasak i jednu ili obje duljine (više u Bašić 2008). U korpusu frazema ovoga rada u omišaljskim su primjerima duljine označene znakom ${ }^{-}$(primjera s dugosilaznim i duljinama u korpusu nije bilo).

U bibinjskom rječniku frazemi su zapisani u kanonskom obliku. Autor je u tim oblicima odlučio tildom zamijeniti osnovu nosive sastavnice te zapisati samo njezine nastavke. Potpuni oblik naglašene nosive sastavnice ispisan je iz oprimjerenja drugih rječničkih natuknica u kojima je nosiva sastavnica "slučajno" upotrijebljena.

Labinski rječnik obiluje akcenatskim nesustavnostima stoga je ekscerpirane primjere provjerila i ispravila dr. sc. Ivana Nežić, na čemu joj zahvaljujem. 
Iz prijašnjih je analiza frazeološke građe poznato da su frazemi u rječnicima čakavskih govora »prezentirani na dva načina: kao dio rečenice kojom se ovjerava uporaba natuknice, ili su izdvojeni zasebno unutar natukničkoga članka, te su obično i grafički drukčije označeni« (Bogović 1997:124). Stoga se korpus frazema sa somatskom sastavnicom ruka sastoji od frazema koji su u rječnicima izvornih čakavskih govora bili izdvojeni zasebno unutar natuknice $r u k a$, a taj je početni popis upotpunjen frazemima pronađenim $u$ rečenicama kojima se ovjeravaju uporabe drugih natuknica. Pretraga drugih natuknica bila je potrebna i zato što se nastojalo da u korpus uđu svi frazemi koji imaju sastavnicu ruka bez obzira na to je li ruka primarna (držat ruke u žepu, imat pune ruke posla (dela), stavit ruku na panj za koga...) ili sekundarna sastavnica (ćapat kruh u ruke, imat libar va rukah, na prste (naprste) jene ruke moći zbrojiti (nabrojit) koga, ča...) (Kovačević 2012:19). Frazemi s rukom kao sekundarnom sastavnicom najčešće su se pronalazili u dijelovima natukničkoga članka primarne frazemske sastavnice. $^{5}$

Svi su pronađeni frazemi ispisani u oblicima i sa značenjima koja su u rječnicima zapisana i ispisana su sva oprimjerenja ${ }^{6} \mathrm{u}$ kojima je sastavni dio rečenice frazem sa sastavnicom ruka.

Usustavljene su 173 frazemske natuknice sa somatskom sastavnicom ruka za koje su zabilježene potvrde u rječnicima izvornih čakavskih govora.

Iako se $\mathrm{u}$ radu pokušalo frazeme promatrati $\mathrm{u}$ užem smislu, $\mathrm{u}$ promatranom je somatskom korpusu ostalo nekoliko poslovica i izreka (ruka ruku mije (pere), ruka $t i$ se posvetila $<!>$, nisu ni svi prsti na ruki jedna-

5 U nekim se govorima, uz praslavenski somatizam ruka, upotrebljava i romanizam man, mano (tal. mano). U korpus frazema nisu ušli konceptualno bliski frazemi sa sastavnicom man, mano, npr. frazem drìo mân (Vis) za koji autor daje značenje 'za rukom (poći)' s primjerom Tồ je svê išlo drìo mân. (u istom se rječniku ne bilježi konceptualno blizak frazem gre (ide; poć će) za rukun $k o m u<c ̌ a>$ ). U istom se govoru za frazem de sekônda mân (Vis) značenja 'od druge ruke; drugog ranga, koji pripada(ju) drugom razredu, koji su drugorazredni' s primjerom U parvû klãsu bîli su gospodâ. U drügu klãsu, takozvõni de sekônda mân. U trëću, teźôcì i teźacìce. bilježi konceptualno blizak frazem od sridnji ruki značenja 'koji pripada srednjem staležu' U gospolskë küće i onë od srîdnji rūkì naprôvan je bôr. (Vis).

6 Potraga za oprimjerenjima frazema ponekad je samo naoko davala rezultate. Na primjer, slika pripitomljene životinje koja jede iz ruku svojega gospodara motivirala je nastanak frazema isti iz ruke komu koji je razvio značenje 'pitomo se ponašati, biti pokoran komu'. Oprimjerenja Va rôvnicami je cudo pitoma, î mi z rukê. (Ist) i Mojê ôvce nisü plähe kakò susëdove. Mojè će ti îst z rūkê, a njegöve kakồ djâvli bižû od čovìka! (Nov) stoga nisu zapisana kao potvrde uporabe frazema jer se doslovno odnose na pitome životinje, a ne na ljudsko ponašanje. 
ki...). Uočeno je, također, da su u nekim proučavanim rječnicima kao frazemi zapisani izrazi u kojima sastavnica ruka ima jedno od svojih metonimijskih značenja. Na primjer, ruka u značenju 'rad, posao obavljen rukama' u frazemu platit ruke Za rûke san mälo plâti. (Mrk), ruka u značenju 'premaz' u frazemu dat (pasat, proć i sl.) jednu ruku Pr̀vu rûku ću u kužîni pruốci s jāpnûn. (Riv) ili ruka u značenju 'ispomoć, pomoć' u frazemu dat <jenu> ruku komu Šime, dàj stricù rûku. (Riv). ${ }^{7}$ Ovi i ovakvi primjeri ostali su u promatranom somatskom korpusu jer ih većina autora ekscerpiranih rječnika navodi i obrađuje kao frazeme iako je s frazeološkog stajališta upitno možemo li takve sveze smatrati frazemima (usp. Kovačević 2012:11-12).

\section{Frazeografska obradba frazemskih natuknica nadnatuknice RUKA}

Prije skoro 20 godina pisano je o problemima izrade višedijalektnoga frazeološkog rječnika (Menac-Mihalić 2002). Problemi koji su bili opisivani u tom članku uspješno su riješeni u nizu dijalektnih frazeoloških rječnika iste autorice (Menac-Mihalić 2005; Maresić-Menac-Mihalić 2008; Menac-Mihalić-Antica Menac 2011). Pri izradi somatskoga frazeološkog rječničkog članka oprimjerenog građom iz objavljenih rječnika koristila su se već opisana i provjerena rješenja iz navedene literature.

Rječnički članak započinje s uopćenom ${ }^{8}$ nadnatuknicom RUKA.

Ako je frazem oprimjeren, na temelju tog oprimjerenja određuje se uopćeni frazem i značenje. Prateći uzore već objavljenih sintetskih frazeoloških studija, kao uopćeni frazem ne donosi se onaj sa samoglasničkim pomakom niti diftongacijom. U uopćenim se frazemima donose oblici koji su češće potvrđeni, a ako postoji potvrda samo iz jednoga govora u uopćenom se frazemu donosi oblik potvrđen u tom govoru. Radi toga će određene natuknice biti s glagolom bez njegova vidskog parnjaka (npr. dignut (vrči) ruku na koga) ili bez određene rekcije ukoliko vidski parnjak i rekcija nisu oprimjereni (bez obzira na to što se može pretpostaviti da postoje).

Poteškoća na koju se naišlo pri ispisivanju korpusa i njegovu usustavljivanju je spoznaja da su frazemi sa somatskom natuknicom ruka u većini proučavanih rječnika ispisani samo u kanonskom obliku kao dio rječ-

7 Riječ ruka u hrvatskom jeziku označava »1. anat. a. jedan od gornjih udova ljudskog tijela od ramena do vrhova prstiju; b. šaka (od zglavka do prstiju); 2. rad uložen u proizvod, posao; 3. sloj pri bojenju, premaz; 4. ispomoć, pomoć; 5 . izvor informacija $\ll$ (HER:1146).

8 Uopćenom u odnosu ruka - diftongirani oblik ruoka/ru oka (Bolj, Orb, Paz). 
ničkog članka ruka bez oprimjerenja. Uz prije spomenuti razlog da je frazeologija u dijalektnim rječnicima uvijek sekundarni cilj, može se pretpostaviti kako je razlog odabiru samo kanonskog oblika frazema i taj što su autori smatrali ili pretpostavljali da ih nije potrebno oprimjeriti jer se "ne razlikuju" od onih u drugim hrvatskim govorima, odnosno da je njihova uporaba poznata, a značenje predvidivo. ${ }^{9}$ Kako je leksikografska i frazeografska stručnost autora rječnika različita, različiti su bili i zapisi kanonskoga oblika frazema u kojima su često izostale oznake za rekciju (npr. dàt odrĩ̌sene rûke $(\mathrm{Vrb})>$ dat odrešene (slobodne) ruke komu), ${ }^{10}$ često nisu navedene mogućnosti uporabe vidskoga parnjaka glagola (npr. prät rûke (Kon) $>$ oprat/prat $<$ svoje $>$ ruke od čega), nije navedena moguća kolokativnost (npr. ìspod rūkẽ (Bla) > ispod ruke [kupit, prodat, nabavit]) ili se pri izvođenju njihova kanonskog oblika nije uzela u obzir mogućnost njihova uključivanja u rečenicu (npr. odníti kàj rūkòn $(\mathrm{Bib})>$ kaj $<$ s $>$ rukon $<$ da $>$ je ki uzel (odnija) ča).

Težište je interesa u izradi višedijalektne frazeološke rječničke natuknice na oprimjerenjima frazema koji pokazuju pravu sliku uporabe frazema u mjesnim govorima, ali se ne smije zanemariti činjenica da je određeni frazem $s$ točno određenim značenjem samo i zabilježen u kojem govoru. Stoga je za potrebe ovoga rada odlučeno da će ekscerpirani kanonski oblici biti informativno navedeni pod značenjima koja su naveli autori rječnika, iza oprimjerenja nakon oznake *. Ti se kanonski oblici neće uzimati u obzir pri uopćavanju frazemskih natuknica ako postoji barem jedno oprimjerenje.

z rukami i nogami svim snagama $Z$ rukàmi $i$ nogämi jū $j$ zakâlîl. $(\mathrm{NV}){ }^{*} z$ rukämi i z nogämi (Mrk) rukãmima i nogãmima (Vrb)

Od 173 usustavljene frazemske natuknice, za njih 143 pronađene su ukupno 362 potvrde (ponekad i više rečenica iz jednoga izvora za značenje jednoga frazema). Kako 30 ekscerpiranih kanonskih oblika nije imalo ni jednu rečeničnu potvrdu, nije postojala mogućnost validnog izvođenja uopćenoga frazema, ${ }^{11}$ stoga su te frazemske natuknice navedene $u$ obli$\mathrm{ku}$ u kojem se nalaze $\mathrm{u}$ rječnicima. ${ }^{12}$ Kako bi se ti primjeri razlikovali od

9 Na primjer, bibinjski rječnik ponudio je pedeset i tri frazema sa somatskom sastavnicom ruka u kanonskom obliku. Za samo petnaest frazema pronađena su oprimjerenja - pod drugim natuknicama rječnika.

10 Prvi je oblik frazema kako je naveden u rječniku, a drugi je oblik frazem pod kojim je prvi oblik obrađen u frazeološkom članku ovoga rada.

11 Na primjer, može se samo pretpostaviti da bi se kanonski oblik pasàt kròz rūke (Bla) značenja 'oprati rublje na brzinu, ručno' trebao uopćiti u frazem pasalo je kroz ruke komu ča.

12 Pridržavajući se pri tome osnovnih načela grafičkog uređenja uopćenih frazema. 
uopćenih frazema s oprimjerenjima, njihov će oblik u rječničkoj obradi biti podvučen crtom.

lavurat priko ruke površno, nemarno raditi * lavurät priko rukẹ (Dra)

Upravo ovakvi slučajevi pokazuju potrebu za dodatnim terenskim istraživanjima koja bi bila usmjerena na oprimjerivanje takvih frazeoloških praznina.

Iako autori možda nisu bili vješti pri izradi kanonskoga oblika frazema, većinom su bili vješti u određivanju njihova značenja. To je pogotovo vidljivo kod polisemnih frazema iako ih autori nisu nužno i tako označavali. Na primjer, pored kanonskoga oblika frazema däti rûku (Rak) zabilježeno je značenje 'pružiti pomirenje, pomoći', a frazem je oprimjeren rečenicom Sêstra njin j prova dâla rûku pökle tolìko vrìmena. (Rak). Frazem je obrađen pod uopćenim frazemom dat <jednu> ruku komu'1. pomoći komu u kakvu poslu, pomoći komu u teškim okolnostima, ponuditi spas komu 2. nuditi prijateljstvo komu, nuditi pomirenje $k o m u^{\prime}$. U pretrazi je izvora pronađena potvrda za prvo značenje ('pomoći'), a ponuđeno oprimjerenje frazema zabilježeno je kao potvrda drugoga značenja ('pružiti pomirenje') uopćenoga frazema.

dat <jenu> ruku komu 1. pomoći komu u kakvu poslu, pomoći komu u teškim okolnostima, ponuditi spas komu (...) Dâj mi jênu rûku, ču prìje finuti. (Rak) Šime, dàj stricù rûku. (Riv) Drāgò mi je dâl rûku. (Senj) Ivić je blažen, neće proć uz čovika ki dela, a da mu ne da ruku. Niki njoj ni dal ruku dok je tribalo dicu zgojit. (ŠiK) Dâj mi rûku vô dìgnit. (Tro) Hôćete non dât rûku za namìstit bãcvu. (Vis) * dät rûku komu (Cri) dàt (jednù) rûku (Omi) dàt rúkū (Spl) dät rûku (Vrb) 2. nuditi prijateljstvo komu, nuditi pomirenje komu Sêstra njin j prôa dâla rûku pökle tolïko vrìmena. (Rak) * dàt rûku komu (Cri)

U nekoliko se slučajeva dogodilo da je značenje frazema utjecalo na promjenu rekcije. U tim se slučajevima rekcija bilježi ispred samoga značenja u oblim zagradama.

na ruku je komu 1. (ča) prikladno je komu što, odgovara komu što Nĩ mi nã ruku lavurät na ovù bôndu. (Hva) Nĩ mi nä ruku bäcat nädesno. (Kon) Nije mi oni vìto nà ruku, jâko je dèzbānde, pa malo tamo idem. (Kun) Kad buôden šã zduôlon, ću poglëdat za armaruône va butiêge od ${ }^{\circ}$ mobilije, tr će mi bìt jüšto na ruôko. (Paz) * bìt nä rūku (Omi) 2. (ki) na usluzi je komu tko, spreman je pomoći tko komu, od pomoći je tko komu Vã̃vek mi je bîl na rûku, kada gôt je mõgal. (Bel) Onä je dobrä sūsëda, vävēk je säkēmu nä rūku. (Kas)

$\mathrm{U}$ određenim je frazemima došlo do srastanja nosive sastavnice ruka s prijedlogom (doruke je komu ča, došlo je (dojde) podruke komu ča, naruku je komu $(\check{c} a)(k i)$, nenaruku je komu ča, nizruku je komu $\check{c} a$, prat (virati) naruke $\check{c} a$, sneruke je komu $\check{c} a$, zvanruke je komu $\check{c} a$ ). Time je dobiven 
novi strukturni oblik frazema s opriloženom sastavnicom, tj. prilogom. ${ }^{13}$ Iako bi se prema frazeografskim pravilima, zbog strukture, ti frazemi trebali obraditi pod svojim nadnatuknicama (prilozima DORUKE, NARUKE, NARUKU, NENARUKU, NIZRUKU, PODRUKE, ZVANRUKE) i ne bi trebali biti zapisani pod nadnatuknicom RUKA, zbog paralelizma s postojećim frazemi$\mathrm{ma}^{14}$ donose se iza pripadajućega uopćenog frazema sa sastavnicom ruka od kojega su nastali, što je grafički istaknuto uvlačenjem, tj. stvaranjem podčlanka. ${ }^{15}$

prat (potezat, šit itd.) na ruke ča ručno prati (potezati, šiti itd.) što Pērlîn se rābîl dokla nî bîlo mäkīn za prät, dôklì sē j prâlo nà rūke. Štramäci su se nä rūke prošĩuäli. (Gro) Prî se svề prãlo nã ruke; vếce rûke nëgo materijôl! (Hva) Sâmo je to činila i ù dva dana ga je nà ruke spléla. Ù ratu se pàsta činila nà ruke, a sad je ima svake lîpe sôrte. (Kun) Od potèzanja püne mrïže nä ruke rûke ti se šundräju! Nî pr̀vo rïbariman bîlo läko. (Nov) Ćemo perievät na ruôki? (Orb) Jöš ka sen ja imêla ovïh mojìh dẽc, jà sen nin sùla svè na rûki. (Orl) (...)

prat (virati) naruke ča ručno prati (dizati) što Va Marsëju uvik vira, majna; sve smo murali viràti näruke. (Ist) Mät je svü röbu prâla näruke. Još tetä držî konöbi maštêl čà se je pr̈vo va njemü röbu prâlo näruke. (Nov)

Radi ekonomičnosti, frazemi koji imaju različita kategorijalna značenja, tj. frazemi koji se ovisno o kontekstu realiziraju kao pridjevski ili kao priložni, obrađeni su pod jednim uopćenim frazemom.

13 Nema čvrstih pravila kada neka prijedložno-imenička sraslica postaje prilog (Babić 2002:563). Babić te sraslice dijeli u dvije skupine i daje prijedloge njihova zapisa: »a) veze koje se upotrebljavaju u jasno prenesenu priložnom značenju pa su postale pravi prilozi, i pišu se zajedno. b) veze koje se stalnije ili češće upotrebljavaju kao priložne oznake u osnovnom ili frazeološkom, idiomatskom značenju pa se zbog slabijega ili jačega prenesenoga značenja mogu smatrati i prilozima, što se katkada očituje i u pisanju jer se pišu i kao jedna riječ. Ako nema posebnih razloga, primjere iz druge skupine valja smatrati priložnim vezama i pisati ih odvojeno« (2002:564). U ovom se radu uvažavaju zapisi autora rječnika, iako su uočene nedosljednosti zapisa.

14 Frazemi doruke je komu ča, nizruku je komu ča i sneruke je komu ča u promatranom korpusu nemaju svoga "para" s neopriloženom imenskom sastavnicom frazema. Kako njihov zapis ne odgovara predloženom sustavu leksikografske obradbe u rječničkoj natuknici RUKA, donosimo ih ovdje:

doruke je komu ča vrlo (posve) blizu je komu što, na neznatnoj udaljenosti je što Popâ je čà mu je bilö dorūkê. (Mrk)

nizruku je komu ča daleko je komu što, na udaljenom je mjestu što Zaminnìt ćemo jâ i Pērè zêmlju. Mèni je nìzruku Gājü, a njëmu Špitālü. (Nov)

sneruke je komu ča nije prikladno komu što, ne odgovora komu što Svratila bi ja dosta puta tebi, ma kad si mi sneruke. (Kun)

15 U primjeru Napr̀ste jene rūkê biš ih moga nabrojît. (Mrk) također se dogodilo opriloženje imenske sastavnice frazema koja u ovom korpusu nije promatrana kao nosiva sastavnica, stoga je njeno opriloženje navedeno kao varijantno u uopćenom frazemu na prste (naprste) jene ruke moći zbrojiti (nabrojit) koga, ča. 
na svoju ruku 1) čudan, neobičan, nepredvidiv, poseban Näš je susèd pämetān, ali mälō j na svojù rûku. (Cri) Õn ti je na svojü rûku i za svõj žêp. (Kas) Ũn je na svòju rûku. (Kon) Govôri bäba da je tetà billa na svojù rûku. (Nov) Uõn ti je mälo na sojö ruôko, ma stëši storĩ sè čâ zäme va ruôke. (Paz) * bìti čovik na svojù rûku (Bib) bìt na svojù rûku (Dra) bìt na svojù rûku (Hva) bìt na svojù rûku (Omi) 2) samostalno, samoinicijativno, po svojoj volji (odluci, inicijativi) Nis te nišs pittâl, tî si së svojevõjno, nâ svoju rûku, störīl. (Gro) Vàvēk su dëlali na svojü rûku. (Kas) Svề je učinìja na svõju rûku prez da je kẽga nïš pità. (Med) Učinil je ôn svề na svojü rûku. (Nov) Š njồn se krščàn nïš ne möre dogovôriti, učìnjena je na svöju rûku (fõzu). (Rak) Iskrcâli su ga na krầj jer je sve činî na svöju rûku, nìkoga me slüša. (Riv) * učinìti (rādìti) na svojü rûku (Bib) rabötot na svojù rûku (Dra) naprävit na svöju rûku (Kon) na svojü rûku (Vrb)

Sintaktička variranja koja su ostvarena variranjem prijedloga uz promjenu padeža (Kovačević 2012) označena su zagradama unutar istoga rječničkog članka.

gre (ide; poć će) za rukun (od ruke) komu ča uspijeva (uspjet će) komu što, ima (imat će) uspjeha tko u čemu, vješt (spretan) je tko u čemu Svè mu ìde za rūkön, štokô posādì svë. Ništa mu ne ïđe od rūkë i prãvi je nesrìtnjak. (Bib) Njemü ne grũe nï̌ od rūokì, kakô da je zäklet. Čâgöt pöčne së mu grie od rūokì. (Bolj) Hudovòjān je jerbô mu nĩ išâ posâl za rūkõn. Grẽ jin od rūkẽ sflonćàt. Spjumbāvânje mu jädno grẽ od rūkẽ, a nïkī i vïruju! (Bla) Së mu grẽ od rūkì. (Cri) (...)

Predložena se frazeološka obradba frazemskih natuknica sa somatskom sastavnicom ruka može vidjeti u Prilogu 1.

\section{Zaključak}

Dijelovi tijela koji su vidljivi i oni koji imaju »izraženiju funkcionalnost (koji imaju više funkcija) i važnost za čovjekov život i opstanak « (Kovačević 2012:125) imaju razvijeniju simboliku koja utječe na oblikovanje frazemskog značenja. »Stoga ruke imaju važno mjesto $u$ frazeologiji, tj. veoma su plodna sastavnica frazema jer se ljudi oslanjaju na slike o rukama koje su zasnovane na svakodnevnom iskustvu o njihovoj uporabi, funkciji, položaju i obliku « (Kovačević 2012:116). Oblikovani rječnički članak koji donosimo u ovom radu sa 173 frazemske natuknice potvrdio je da je ruka vrlo plodna somatska sastavnica i u čakavskim govorima.

Frazemi sa somatskom sastavnicom ruka po svom sastavu i strukturi u bitnom se ne razlikuju od onih u drugim hrvatskim govorima. U obrađivanim frazemima ekscerpiranima iz 39 rječnika izvornih čakavskih mjesnih govora postoje, naravno, fonetsko-fonološke, morfološke, tvorbene i sintaktičke razlike, ali su značenja frazema na cijelom čakavskom području predvidiva i univerzalna. 
Frazemi koji odstupaju od korpusa drugih hrvatskih govora su oni motivirani maritimnim životom (ćapat $<$ na $>$ jednu (dvi, tri) ruki tarcarola, ćapat dvi ruki tarcaluna, dat ruku tarcaluna (tarcarola)) te oni motivirani društvenom stratifikacijom (do veće ruki, judi ol naši ruki, od isti (sridnji, gospolski, težoški) ruki).

Zanimljivi su frazemi koji su potvrđeni na krajnjem sjeveru i krajnjem jugu čakavskoga područja. Frazem ne bi $t k o$ jil (ze) ni orah iz ruke (z ruk) komu, u značenju 'osjeća tko odbojnost (gađenje) prema komu', u proučavanome korpusu potvrđen je jedino u Kuni na poluotoku Pelješcu i u zaselku Mrkoči u središnjoj Istri. Frazem istoga značenja, ne bi ni oraja komu iz ruke ija, zabilježen je u novoštokavskim ikavskim govorima Gale, Otoka i Sinja u Cetinskoj krajini (Menac-Mihalić 2005:257). Frazem imat u rukah i škare i sukno značenja 'imati potpunu slobodu odlučivanja' potvrđen je u zaselku Mrkoči u središnjoj Istri i u Blatu na otoku Korčuli.

Za razliku od navedenih frazema koji su "geografski prošireni" u korpusu je zabilježen i geografski ograničen frazem imat dritu ruku u značenju 'biti precizan u gađanju' zabilježen u zaselku Mrkoči i u Raklju. Frazem je najvjerojatnije motiviran Trkom na prstenac, konjaničkim natjecanjem $\mathrm{u}$ kojem se $\mathrm{u}$ galopu nastoji kopljem nabosti prstenac sastavljen od dvaju križno spojenih kovinskih kružnih prstenova. Natjecanje se svake godine održava u Barbanu, gradiću koji se nalazi točno na pola puta između Mrkoča i Raklja.

Budući da su oprimjerenja ekscerpirana iz objavljene literature i da ekscerpirani frazemi nisu provjereni na terenu, rječnička natuknica RUKA može se smatrati nepotpunom i nedovršenom. Mnogobrojni kanonski oblici koji nisu imali ni jednu rečeničnu potvrdu pokazali su potrebu za dodatnim terenskim istraživanjima koja bi bila usmjerena na oprimjerivanje takvih frazeoloških praznina.

Ruku na srce, imamo pune ruke posla. 


\section{Izvori}

Bel - Velčić, Nikola. 2003. Besedar bejske tramuntane. Mali Lošinj - Beli Rijeka: Katedra Čakavskog sabora Cres-Lošinj - Tramuntana - Adamić. Bib - Šimunić, Božidar. 2013. Rječnik bibinjskoga govora. Zadar: Ogranak Matice hrvatske u Zadru.

BiŠ - Turina, Zvonimir; Antun Šepić-Tomin. 1977. Rječnik čakavskih izraza: područje Bakarca i Škrljeva. Rijeka: Riječko književno i naučno društvo.

Bla - Milat Panža, Petar. 2015. Rječnik govora Blata na Korčuli. Zagreb: Institut za hrvatski jezik i jezikoslovlje.

Bolj - Francetić, Ivan. 2015. Rječnik boljunskih govora. Pula: Sveučilište Jurja Dobrile u Puli.

Bru - Dulčić, Jure; Pere Dulčić. 1985. Rječnik bruškoga govora. Hrvatski dijalektološki zbornik, 7/2, 381-747.

Cri - Ivančić-Dusper, Đurđica; Martina Bašić. 2013. Rječnik crikveničkog govora. Crikvenica: Centar za kulturu »Dr. Ivan Kostrenčić«.

Dra - Šimunović, Petar. ${ }^{2} 2009$. Rječnik bračkih čakavskih govora. Zagreb: Golden marketing - Tehnička knjiga.

Gri - Barbarić, Ivan. 2016. Rječnik griško-belgradskoga govora. Crikvenica: Centar za kulturu »Dr. Ivan Kostrenčić«.

Gro - Lukežić, Iva; Sanja Zubčić. 2007. Grobnički govor XX. stoljeća (gramatika i rječnik). Rijeka: Katedra Čakavskog sabora Grobnišćine.

Hva - Benčić, Radoslav. 2014. Rječnik govora grada Hvara. Hvar: Muzej hvarske baštine.

Ist - Smoljan, Ante. 2013. Rječnik govora otoka Ista. Zadar: Matica hrvatska, Ogranak Zadar.

Kas - Miletić, Cvjetana. 2019. Slovnik kastafskega govora. Kastav: Udruga Čakavski senjali Kastav.

Komp - Kranjčević, Milan. 2004. Ričnik gacke čakavšćine: konpoljski divan. Otočac - Rijeka: Katedra Čakavskog sabora pokrajine Gacke - Graftrade.

Kun - Vodopić, Nina. 2006. Kunovske stare riči. Kuna: vlast. naklad.

Lab - Milevoj, Marijan. 2006. Gonan po nase: rječnik labinske cakavice. 2. izmijenjeno i dopunjeno izdanje. Labin: Mathias Flacius.

Med - Peruško, Marija. 2018. Frazeološki rječnik medulinskoga govora. Medulin: Općina Medulin.

Mrk - Runko, Radoslav. 2014. Rječnik govora zaseoka Mrkoči u Istri. Rijeka: Naklada Kvarner.

Mur - Juraga, Edo. 2010. Rječnik govora otoka Murtera. Murter - Šibenik: Ogranak Matice hrvatske - Županijski muzej. 
Nov - Vranić, Silvana; Ivo Oštarić. 2016. Rječnik govora Novalje na otoku Pagu. Novalja: Grad Novalja - Ogranak Matice hrvatske u Novalji - Filozofski fakultet u Rijeci.

NV - Sokolić-Kozarić, Josip M.; Sokolić-Kozarić, Gojko M. 2003. Rječnik čakavskog govora Novog Vinodolskog. Rijeka - Novi Vinodolski: vlastita naklada.

Omi - Mahulja, Ivan. ${ }^{2} 2016$. Rječnik omišaljskog govora. Rijeka-Omišalj: Riječki nakladni zavod - Općina Omišalj.

Orb - Kalsbeek, Janneke. 1998. The Čakavian dialect of Orbanići near Žminj in Istria. Amsterdam - Atlanta: Rodopi.

Orl - Houtzagers, H. Peter. 1985. The Čakavian Dialect of Orlec on the island of Cres. Amsterdam: Rodopi.

Pag - Kustić, Nikola. 2002. Cakavski govor grada Paga s rječnikom. Zagreb: Društvo Pažana i prijatelja Paga.

Paz - Gagić, Marija. 2017. Rječnik pazinskoga govora. Pazin - Zadar: Katedra čakavskog sabora Pazin - Ogranak Matice hrvatske u Zadru.

PiZ - Barbić, Ante. 2011. Rječnik Pitava i Zavale. Zagreb: IHJJ.

Pre - Crnobori, Ratko. 2018. Rječnik premanturskoga govora. Medulin: Općina Medulin.

Rak - Percan, Romana. 2017. Frazeološki rječnik Raklja. Diplomski rad. Filozofski fakultet Sveučilišta Jurja Dobrile u Puli. https://zir.nsk.hr/islandora/object/unipu\%3A1820 (pristupljeno 27. siječnja 2020.)

Riv - Radulić, Ladislav. 2002. Rječnik rivanjskoga govora. Zadar: Matica hrvatska Zadar.

Rov - Kalčić, Slavko; Goran Filipi; Valter Milovan. 2014. Rječnik roverskih i okolnih govora. Pazin - Zagreb - Pula: Matica hrvatska Pazin - Naklada Dominović - Znanstvena udruga Mediteran.

Ruk - Mohorovičić-Maričin, Franjo; Franjo Šepić-Bertin. 2001. Rječnik govora Rukavca i bliže okolice. Rijeka: Adamić.

Senj - Moguš, Milan. 2002. Senjski rječnik. Zagreb - Senj: Hrvatska akademija znanosti i umjetnosti - Matica hrvatska Senj.

Spl - Petrić, Željko. 2008. Rječnik starih splitskih riječi i izraza. Split: Naklada Bošković.

Sus - Hamm, Josip; Mate Hraste; Petar Guberina. 1956. Govor otoka Suska. Hrvatski dijalektološki zbornik 1, 7-213.

ŠiK - Bralić, Ivanka. 2014. Čakavske besede moje i sih mojih z Šmrike i Kraljevice. Kraljevica: Udruga u kulturi »Stol«.

Tro - Geić, Duško. 2015. Rječnik i gramatika trogirskoga cakavskoga govora. Split: Književni krug Split - Združeni artisti Trogir. 
Uni - Nikolić, Margita. 2000. Unije - kuželj vaf sarcu. Mali Lošinj: Katedra

Čakavskog sabora Cres - Lošinj.

Vis - Roki-Fortunato, Andro. 1997. Libar viškiga jazika. Toronto: University of Toronto Press.

Vrb - Matković, Dinko. 2004. Rječnik frazema i poslovica govora Vrboske na otoku Hvaru. Jelsa: Ogranak Matice hrvatske Jelsa.

\section{Literatura}

Babić, Stjepan. 2002. Tvorba riječi u hrvatskome književnome jeziku (3. poboljšano izdanje). Zagreb: Hrvatska akademija znanosti i umjetnosti - Nakladni zavod Globus.

Bašić, Martina. 2008. Čekavski rječnik (Ivan Mahulja: Rječnik omišaljskoga govora. Rijeka - Omišalj: Riječki nakladni zavod - Općina Omišalj, 2006.). Rasprave Instituta za hrvatski jezik i jezikoslovlje, 34, 484-490.

Bogović, Sanja. 1997. Frazeologija u čakavskim dijalektološkim rječnicima. Fluminensia, 9, 1-2, 121-132.

Dugandžić, Ana. 2019. Somatski frazemi u hrvatskom i ukrajinskom jeziku. Doktorski rad. Zagreb: Filozofski fakultet.

HER = Hrvatski enciklopedijski rječnik. 2002. Ur. Ljiljana Jojić i Ranko Matasović. Zagreb: Novi liber.

Kovačević, Barbara. 2012. Hrvatski frazemi od glave do pete. Zagreb: Institut za hrvatski jezik i jezikoslovlje.

Lisac, Josip. 2009. Hrvatska dijalektologija 2. Čakavsko narječje. Zagreb: Golden marketing - Tehnička knjiga.

Lisac, Josip. 2018. Nad kartama hrvatskih dijalekatnih rječnika od 1990. do 2015. Cakavska rič, 46, 1-2, 159-167.

Maresić, Jela; Mira Menac-Mihalić. 2008. Frazeologija križevačko-podravskih kajkavskih govora s rječnicima. Zagreb: Institut za hrvatski jezik i jezikoslovlje.

Menac-Mihalić, Mira. 1998. Izrazi za 'malo' u čakavskim rječnicima. Filologija, 30-31, 267-271.

Menac-Mihalić, Mira. 2002. Problemi izrade višedijalektnoga frazeološkog rječnika. Filologija, 38-39, 49-55.

Menac-Mihalić, Mira. 2005. Frazeologija novoštokavskih ikavskih govora u Hrvatskoj: s rječnikom frazema $i$ značenjskim kazalom s popisom sinonimnih frazema. Zagreb: Institut za hrvatski jezik i jezikoslovlje - Školska knjiga.

Menac-Mihalić, Mira; Antica Menac. 2011. Frazeologija splitskoga govora s rječnicima. Zagreb: Institut za hrvatski jezik i jezikoslovlje. 
Moguš, Milan. 1985. Nacrt za 'Rječnik čakavskoga narječja'. Hrvatski dijalektološki zbornik, 7, 1, 319-336.

Vulić, Sanja. 1988. Struktura čakavskih dijalekatnih rječnika. Magistarski rad. Zagreb: Filozofski fakultet.

Vulić-Vranković, Sanja. 1997. Metodologija uvrštavanja frazema u rječnike izvornih čakavskih govora. Riječ, 3, 2, 115-123.

Vulić-Vranković, Sanja. 1999. Frazemi u rječnicima izvornih čakavskih govora. Čakavska rič, 27, 1, 29-41.

Vulić-Vranković, Sanja. 2003. Leksikografska obradba frazema u budućem velikom sintetskom rječniku izvornih čakavskih govora. Fluminensia: časopis za filološka istraživanja, 15, 1, 43-56.

\title{
Somatic phraseological units with the component ruka (hand) in Čakavian vernaculars
}

\begin{abstract}
The paper deals with somatic phraseological units with the component ruka (hand) excerpted from the published dialectological dictionaries of Čakavian vernaculars. Based on the corpus of 173 phraseological entries, the high productivity and predictability of the meaning of phraseological units with the component ruka were confirmed.
\end{abstract}

Ključne riječi: dijalektna frazeologija, čakavski govori, frazemi, somatska sastavnica ruka

Keywords: dialectal phraseology, Čakavian idioms, phraseological units, somatic component ruka 


\section{Prilog 1.}

Frazemske natuknice ispisane su podebljanim slovima. Frazemske natuknice bez oprimjerenja i koje su navedene $u$ obliku $u$ kojem se nalaze $u$ rječnicima dodatno su i podvučene. $U$ dijelu je frazema ukošenim slovima naznačena rekcija ili neki drugi oblik upute. Okrugle zagrade ( ) označuju međusobno zamjenjive odnosno varijantne komponente frazema, $\mathrm{u}$ izlomljenim zagradama $<>$ donose se izostavljivi odnosno fakultativni dijelovi, a uglate zagrade [ ] ukazuju na kolokativnost frazema. Vidski su parnjaci odvojeni kosom crtom. U kosim zagradama iza značenja frazema iskazano je tematsko ograničenje u uporabi određenoga frazema. Ako je frazem višeznačan svako od njegovih značenja obrojčano je brojkama zapisanim podebljanim rednim brojevima. Različito kategorijalno značenje također je obrojčano, ali su brojevi zapisani podebljanim brojevima iza kojih je zagrada. Oprimjerenja se navode abecednim redom kratica mjesnih govora koji se donose u zagradama. Iza znaka * nalaze se neoprimjereni frazemi, tj. u rječnicima ponuđeni kanonski oblici. Uvučeni su novi strukturni oblici frazema s opriloženom sastavnicom.

\section{RUKA}

batit ruke aplaudirati, pljeskati * bätit rúke $(\mathrm{Spl})$

bit čija produžena ruka biti čije sredstvo (način) u postizanju (ostvarenju) cilja Õn mū j prodũžena rūkä, dëlā së čà se ovômulovêmu grūstî. (Gro)

bit desna ruka komu biti velika pomoć (oslonac) komu Õn mū j dêsnā rūkà! (Cri) Onä mī j dêsnā rūkä, čà bìn bež njê? (Gro) Ôn je mèni dèsno rūkà. (Hva) Ũn mi je dèsna rûka. (Kon) Näši vrîdni sîni su nan dèsna rũka u sväken dëlu. (Med) Ti mâli je njìma dèsna rûka. (Rak) * dêsna rūkà (Mrk) bìt dèsna rūkà $(\mathrm{Vrb})$

bit marjoneta u čijin rukan raditi što hoće tko s kim Ma čà pensâš da möreš s nämon sâd ovãko, sâd onãko, nîs ja marjonëta u tvojìn rukän! (Med) * bit u čigòvih rukäh (Mrk)

bit srićne ruke $<u$ čemu $>$ imati sreće (uspjeha) $<u$ čemus, uspijevati $<u$ čemu> Uzmì löt zõ me, tĩ si srḯnie rukiê. (Dra) Onâ j srìćnē rūkê. Vâvīk dobîje na tõmbuli. (Gro) * bìti srìtne rūkè (Bib) bìt srìtne rukê (Hva) bìt srìtne rukê (Kon) bìt srḯne rukiê (Vrb)

bit široke (dobre, obilate) ruke biti darežljiv (velikodušan), rado (lako) darivati Njegà pĩtaj, õn je širokê rūkê. (Gro) Bîl je ôn dobrê rūkê i nïkad nî päzil na sitnîs. Māte je bîl rūkê obiläte. (Nov) Naši Merikani nisu baš šìrokē rūkè, aš do dolara ni lahko doć. (ŠiK) * bìti širöke (döbre) rūkè (Bib) širökeh rûk (BiŠ) bìt döbrē rūkẽ (Bla) bìt pödatne (prüžene) rukê (Kon) bìt lëhkē (läškē) rūkì (Omi) bìt širöke rukiê (Vrb) 
bit tvrde ruke biti škrt Õn je tor̀de rūkẽ. (Dra) Tvõrde je rukiê. (Vrb)

bit u čijin rukan biti pod čijim nadzorom Dìd je u ošpitãlu u rukàn enêganàpro dobrêga mêdiga. (Med)

bit $\mathbf{u}$ dobrih rukah biti siguran $u z$ koga, biti u sigurnim uvjetima Mâla je vềro u dobrïh rukäh. (Rak) * bìt u döbri rukâ (Kon) bit u dobrìh rukäh (Mrk)

biti vezani ruk biti nemoćan, biti bez prava i ovlasti * bìti vēzàni rũk (Bib)

Bogu $<\mathbf{v}>$ rukah nesigurno, predodređeno Duhtôri su storìli čà su mogli, a sâd je sề Bögu v rukäh. (Gro) Svè smo učìnli i sâd je svề Bögu rukâh. (Nov) * bit Bögu u rukäh (Mrk)

ča $m u$ oči vide, to $m u$ ruke store (načine) svestran i vješt je majstor tko Un se va sve itindi, ca mu oci vidu, to mu ruke cinu. (Ist) Čà mu öči vìde to mu rûke store. (Mrk) Ča mu öči vìde, to mu rûke nâčine. Svë ča mu öči vìde, njegồve rûke če načinìti. (Rak)

ćapat $<$ na $>$ jednu (dvi, tri) ruki tarcarola podvezati jedro prvim (drugim, trećim) redom priveznica, skratiti jedro za jedan (dva, tri) jedreni vez * ćapät jednü, dvî, trî rûki tarcarôla (Omi) na jednü, na dvî, na trî rûke tarcaruôla (Uni)

ćapat dvi ruki tarcaluna ponašati se s najvećim oprezom Mãlo si se nãpi, ćapô si dvî rûke tarcalūnä. (Dra) * ćapät dvî rûki tarcarôla (Omi)

ćapat kruh u ruke završiti školovanje, izučiti zanat * ćapàt krüh ù rūke (Bla) ćapàt krüh ü ruke (Hva) ćapàt krüh ü ruke (PiZ)

daj prst $\langle k o m u\rangle$, zet će $\langle\mathbf{t i}\rangle$ celu ruku pohlepan je $t k o$, nikad nije dosta komu, nezahvalan je tko, zloupotrebljava dobrotu tko Dãj pärst, zẽt će ti cẽlu rûku. (Bel) Dãj mu pr̀st, zẽt će cẽlū rûku. (Cri)

daš prst $k o m u$, a on $<\mathbf{t i}>$ zame celu ruku pohlepan je $t k o$, nikad nije dosta komu, nezahvalan je tko, zloupotrebljava dobrotu tko Dâš mu pr̀st, a ôn ti zäme cêlū rûku. (Gri) Dâš mu pr̀̀s, a ôn zäme celu rûku. (Mrk)

dat ruku tarcaluna (tarcarola) podvezati jedro prvim redom priveznica, skratiti jedro za jedan jedreni vez Dôj rûku tarcalūnà jer je u konōlü vēli vìtar. (Dra) Duali smo inu ruku tarcarola. (Ist) * dàt (ćapàt) rûku tarcarūlà (Hva) dàt rûku tarcarôla (Omi) dât rûku tarcalūnâ (Vis)

dat (indikat, bacit) prvu (drugu, treću, zadnju itd.) ruku nanijeti prvi (drugi, treći, zadnji itd.) premaz /ob. boje/ Izgléda da mu se prëšilo pa je na jôš môkru pr̃vu rûku dāväja finu. (Bib) Piturô son bruôd, däćcu mu jöš zônu rûku. (Dra) Jöš mörān dät zädnju rûku i sä piturìja je gotôva. (Kas) Cä si dô pr̀̀o rûko mînija? (Lab) Smo dâli zîdin prou rûku, jôš ćemo dvì pa će bìti lîpo bĩlo. Sütra ćemo dàti zädnju rûku zîdin. (Med) Dâ je pròu rûku pitüre. (Mrk) Pred dèset dân san jâ indikâl pròu rûku u stâromu tr̀sju. (Nov) Jôš jedãnpūt pinelã dājè drùgù rûku. (NV) Dô san do pộdnệ parvû rûku. (PiZ) Kad se ošûši šprüc, ceèmo dàt drügu rûku. (Pre) Bĩlimo kužĩnu i smồ dâli zädnju rûku. 
Martina Bašić: Pune ruke posla - frazemi sa somatskom sastavnicom ruka u rječnicima...

FILOLOGIJA 75(2020), 67-97

(Rak) Bacîl san pr̀vu rûku biljãfke po zīdù. (Senj) Opêna smo dôli jednù rûku, a vajãt će jöś dât bârź i dvî rûke. (Vis) * dät (parvû, drügu... zôdnju) rûku (Hva) dàt drùgu rûku (Tro) dàt parvû (drügu) rûku (Vrb)

dat (pasat, proć) jednu ruku nanijeti jedan premaz /ob. boje/ I dr̀venon je brödu dobrö dàti jednù rûku minije prìja köpera. (Bib) Kühinjo smo pasäli

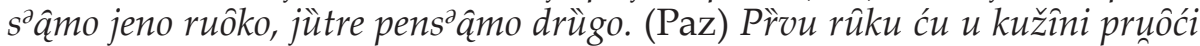
s jāpnûn. (Riv) Opêna smo dôli jednü rûku, a vajãt će jôś dât bârź i dvî rûke. (Vis) * dàt rûku (Hva) dàt rûku pitûre (Omi)

dat $<$ jenu> ruku komu 1. pomoći komu u kakvu poslu, pomoći komu u teškim okolnostima, ponuditi spas komu Dâ mi je rûku röjāk Mârko. Pérë mi je ökrīvān, pak će sìgūro dät rûku. (Bla) Äjde däj mi rûku jër ne smîn sâm dìgniti têško rädi töga vratrijêga brüka. (Bib) Dôj mi rûku da napàrtin žĩoo. (Dra) Dä mi je barênko ǐkor dõša dät rûku, bî bi vêj gotôv. (Hva) Se pêntin da mu nîs dâ ènu rûku kad su pilìli dr̃oa. (Med) Zvâne, bìte nan jenu rûku dâ? Dâli smo mu jenu rûku da proo fini. (Mrk) Da si me zvâl kad si krôv pokrīvâl, bîl bi ti jâ dôšal dàt rûku. (Nov) Daj nan v ûde rûku da dìgnemo koâr od fośâ. (Pag) Ceš nan prît jütre dàt jêno ruôko, ćemo tr̀gat? (Paz) Zanamìsto da si nan dọšsa dàt rûku, a tĩ si dọ̃ša zanovệtät. Dôj brâtetu rûku! (PiZ) Dâj mi jènu rûku, ču prìje finuti. (Rak) Šime, dàj stricù rûku. (Riv) Drāgồ mi je dâl rûku. (Senj) Ivić je blažen, neće proć uz čovika ki dela, a da mu ne da ruku. Niki njoj ni dal ruku dok je tribalo dicu zgojit. (ŠiK) Dâj mi rûku vô dìgnit. (Tro) Höćete non dât rûku za namìstit bãcou. (Vis) * dät rûku komu (Cri) dàt (jednù) rûku (Omi) dàt rúkū (Spl) dàt rûku (Vrb) 2. nuditi prijateljstvo komu, nuditi pomirenje komu Sêstra njin j pr̂a dâla rûku pökle tolìko vrìmena. (Rak) * dät rûku komu (Cri)

dat dobre ruke dragovoljno dati više nego što je ugovoreno, preplatiti $D o ̂$ mu je döbre rukê. (Hva)* dòbrē rúkē (Spl) dät dõbre rukẽ (Tro)

dat kruh u ruke komu omogućiti komu da se samostalno uzdržava (zarađuje za život), pripremiti koga za život, postaviti koga na noge Svì je dìci dôl krüh ù ruke. (Vis) * dät kòmu krûv u rûke (Kon) dät krüh u rûke (Mrk) dàt krüh ù ruke (Vrb)

dat odrešene (slobodne) ruke komu dati komu slobodu djelovanja, omogućiti komu da radi slobodno (neovisno od drugih) Rëkāl mī j nëka tô jä storîn i dãl mi odrẽšene/slöbodne rûke. (Gro) * däti kömen slöbodne rûke (Bib) dàt odrĩ̌sene rûke (Vrb)

dat ruku odseć za koga jamčiti za koga, imati puno povjerenje $u$ koga, čvrsto vjerovati Ma za njü bìn i rûku dâla odsëć! (Cri)

dat se u ruke potući se /šakama/ Jōš ći ucinìt da se muśkì dōdù ù ruke. (Vis) * ćapàt se ù ruke (Dra) ćapãt se (dōvãt se / dãt se) ü ruke (Vis) ćapàt se (dät se) ù ruke (Vrb) ćapàt se v rûki (Omi) 
Martina Bašić: Pune ruke posla - frazemi sa somatskom sastavnicom ruka u rječnicima...

FILOLOGIJA 75(2020), 67-97

dat si ruku dogovoriti se, pogoditi se Dâjmo si rûku pa da finemo kuntraštĩvat. (Pre)

dat u ruke ča komu povjeriti komu što Hârte su dâli okâtu u rûke. (Med) Ne mòreś tî tô njèmu dât ü ruke, ôn će ti svè ispaśtroćât. (Vis)

davat po ljučkeh rokah posuđivati Ta mäkina je prevëć delikâta, nĩ za dāvät po ljüčkeh rokäh. (Paz)

dignut (vrči) ruku na koga udariti koga, istući koga, napasti koga Kad bi dōša $i$ molìja da mu prôstin što je dìga rûku nã me, pa brät mi je. (Bib) Nikad jõ nīsôn dìgo rûku na cệr. (Dra) Nemôi, sĩnko, dìgnit rûku na sestrù svojû! (Hva) Nĩje nìkad dìga rûke na dĩte. (Med) Je dìga rûke na ôca, znâš. Ni mu bîlo têško vřč̀i rûke na ôca. (Rak) * dìgniti rûku na kòga (Bib) dìgnut rûku na kòga (Kon)

dignut ruku na sebe pokušati ili izvršiti samoubojstvo Marìja je dìgla rûku na sëbe, ča njoj je bîlo, nîdan ne znâ. (Rak)* dìgnut rûku nã se (Kon)

dignuti/dizati ruke <od koga, od čega odustati/odustajati <od koga, od čega $>$, prestati se brinuti <za koga, za što>, napustiti/napuštati koga, što Ne mörēn vìše, dižên rûki od tebè!! (Cri) Se štufâ batöriti š njîman i je dìga rûke od svẽga, je pôša ćâ. (Med) * digniti rûke od čega (Bib) dìgnut rûke od kòga ili čèsa (Kon) dìgnit rûke od köga / od čèga (Vrb)

do veće ruki koji pripada višem društvenom staležu * do vēće rukì (Orl) dobiti ključ u ruke useliti se u opremljen stan * döbiti kljũč ù ruke (Bib)

dobra ruka 1. novčani novogodišnji dar /ob. djeci/ Na mlãdo lëto dìca hödijo ot kùći pobìrat dobrô rūokò. (Bolj) Dìci se môrā dàt nï̌ za döbrū rûku. (Gri) Za dobrü rûku sān dobîla postolì. Doneslä mī j cikulâdu za dobrù rûku. (Gro) Za dobrü rûku dèca nösē jäbuku nabodenü na kìticu ružmarîna va kû njin jûdi pìcajū šôlad. (Kas) Za dobrồ rûko vä pût son ot nôni, nôneta, cîji, bôrbeti, ocä i mäteri döbi tolìko bêci dà ćun si kupìt nôvo biciklèto. (Lab) Za Trï krãlja i za Nòvo lìto se dicàn davälo dõbru rûku. (Med) San kupìla dâr ča ćemo ni ponès za dobrö ruôko. (Paz) Za Nòvo lìto, za dõbru rûku bi nan bäba daväla par bonbôni. Bäba bi mi za dõbru rûku dâla šäku mêndula. (Pre) Nikäd su dìca za döbru rûku dobĩvala mêndule, orìhe, smökve, a danäs bi svì stìli sämo šõlde. (Rak) Dali su nan za dobru ruku črviv marun. (Ruk) * dobrä rūkä (Cri) dobra rūkä (Mrk) dobrä rūkä (Omi) döbri rūkì (Vis) 2. napojnica, novčani poklon A c̊ê ćeś mi platit... nêka ti to bûde za döbru rûku. (Bel) O Božiću poštaru vavik dan nič za dobru ruku. (ŠiK)

dočekat raširenih ruk dočekati koga, što srdačno (rado, prijateljski) * dočêkati rašireni rũk (Bib) docëkot rašĩrenih rûk (Hva) dočêkot rašĩrenih rûk (Vrb)

doć (hodit) na ruku komu biti na usluzi komu, biti spreman pomoći komu, biti od pomoći komu Tô mi je hvalä c̊e san ti vãvek na rûku hodĩl. Vãvek mi je hodìla na rũku, vaja i ja njõj neśs udẽlan oli dãn za üzdarje. (Bel) Duõšo mi je nã ruku. (Dra) Pöštèn čovëk ti vâvēk grẽ nä rūku. (Kas) Tä pût mi je mêdih 
šô na rûko i zäjno me je vižitô. (Lab) Držàva je fabrikânten šlà na rûku. (Mrk) So nan šlì na rúoki. (Orb) Smö njîn döšli na rûku, mä ôni su to zâbili. (Rak) Ako ikako more, ona će ti põć na rukü. (ŠiK) Köko son pũtih jô njèmu dõśal nã ruku. (Vis) * iči kômen nä ruku (Bib) dôć kòme nã ruku (Hva) ić kômu nà ruku (Kon) pố nä rūku (Omi)

doć će ruke puno koga puno će stajati koga što Püno ćedu te dọć rûke. (PiZ)

doć u prave ruke biti dodijeljen pravoj osobi, doći na pravo mjesto $T a$ bičiklèta je säda döšla vèro u prâve rûke. (Rak) * dóči u prãve rûke (Bib)

doć u ruke komu doći pod čiju vlast * dóć kòmu ü ruke (Kon)

dojde (došlo je) do ruk $<\check{c} a>1$. uspjelo se što pobrati u polju /a da nije propalo zbog kakve vremenske nepogode/ Ako gröźje śegòdiśja dõje do rũk, bi će vĩna obilàto. (Tro) 2. došlo je do tučnjave Bïźmo ćâ dôklen nĩ dôślo do rũk. (Tro)

dok bi pljesnul rukon ob ruku začas, odmah * dök bi pljësnul rukôn öb ruku (Kon)

došlo je (dojde) pod ruku (ruke) komu 1. (ča) slučajno se našlo na dohvatu komu što Agrampô je onồ ca mü je dõšlo pôd ruku. (Hva) Pozìmāl je së ča mu j' prišlö pöd rūku. (NV) Ukrãla bi uočiglệd svê ča non dọjde pöd ruku. (PiZ) Gre po kući i harači ča god njoj dojde pod ruku. (ŠiK) * duố ü/pöd ruku (Vrb) 2. (ki) slučajno se našlo na dohvatu komu tko Vôlēl bīn da mi pöd ruke dõjde ôn nevajâtī. (Gro) Ako mi dõjde pöd ruke, islomì(t) ću ga! (Hva) * dọć pöd ruke (Dra)

došlo je (dojde) podruke komu ča slučajno se našlo na dohvatu komu što Mõli mi hïće na tlëh svë ca mü dõjde pödruke. (Hva)

držat $<$ sve $>$ konce (harte) $\mathbf{u}$ rukah 1. imati sve pod kontrolom, upravljati situacijom Büdi prëz strâha, brät držì svë kônce u rukäh. (Rak) 2. gospodariti čime, imati vlast nad kim Nevìsta je bĩla žgàja žẽna, je držäla u küći svè hârte u rukàn. (Med) *držăt rëdine u rukäh (Mrk)

držat prekrižene ruke ne raditi ništa * držät prekrižene rûke (Mrk)

držat ruke u žepu ništa ne raditi Po cîle dâne sämo držì rûke u žẽpu. Sâmo držì rûke u žêpu i nìš ne dêla. (Rak) Ôn je prôvi čarlatän, po cêli dôn nì̀c ne dëla $i$ sâmo držî rûki va žepè. (Lab) * držät rûke u žepü (Mrk)

držat u svojin rukah ča gospodariti čime, imati vlast nad kim Grubï̌̌ka je svè držäla u svojìn rukäh. (Rak)

držati ruke u križ ne raditi ništa Najläšve je držăti rûke u krîž i glëdati ča se dëla. (Med)

goli ruk bez oružja (alata), nenaoružan, samo svojom snagom (spretnošću) Pa kî grê u šùmu göli rûk? (Kon)

govorit za rukon komu ometati koga u poslu Ne govorì mi za rukõn. (Senj) 
Martina Bašić: Pune ruke posla - frazemi sa somatskom sastavnicom ruka u rječnicima...

FILOLOGIJA 75(2020), 67-97

grdo ruke kalat (stavljat) na koga udarati koga, tući koga, napadati koga Vì̌se pũti je na žềno gr̂rdo ruôke kalã, ač je prihajềa döma pijããn. Po mojô, në bi rābïlo na nijënega gr̂̀do ruôke stavljãt, ljûden bi muôrala bit dòsta besëda, $k a^{\circ}$ se rečè. (Paz) * stävit rûke na kèga (Mrk) stävit, kläst na kogà rûki (Omi)

gre (ide; poć će) za rukun (od ruke) komu ča uspijeva (uspjet će) komu što, ima (imat će) uspjeha tko u čemu, vješt (spretan) je tko u čemu Svë mu ìde za rūkòn, štokô posādì svë. Ništa mu ne ìđe od rūkè i prãvi je nesrìtnjak. (Bib) Njemü ne grĩe nič od rūokì, kakô da je zäklet. Čâgöt pöčne së mu grie od rūokì. (Bolj) Hudovôjān je jerbò mu nĩ išâ posâl za rūkõn. Grẽ jin od rūkẽ sflonćât. Spjumbāvânje mu jädno grẽ od rūkẽ, a nïkī i vìruju! (Bla) Së mu grẽ od rūkì. (Cri) Neumìćán je, ne grê mu nïš za rūkûn. Ne grê mu nìš od rūkì zâč je ćãnpa. (Gri) Së mi rê od rūkë, blâzi menì! (Gro) Ne grẽ mi od rukê. (Hva) Ne rẽ mi od rūkì. Nëkada mi së grẽ od rūkì, nëkada ni za Böga mïlēga da storîn. (Kas) Grẽ mu za rukôn. (Kon) Danäska nan je dëlo hodìlo ot rukì, päk smo naprävili trî srima na vên flëce. Na së fôzi je otê doznät s kên je njegöva hcì dobïla mûlca, ma mu tô nî šlò za rûkon. Ne vêrvan dà će nan pố za rûko ankorät se z vên špôgon. (Lab) Je srïćan čovïk, mu je pöšlo za rukôn čùda tẽga ča je napensä. (Med) Švaltìvanje njin je šlö za rūkôn. Tr̀̀sila se je, ma njoj nî šlô za rūkôn. (Mrk) Näšoj mâloj sväki posâl grê od rūkê! Ako têbi otâj posâl grê od rūkê, bït će püna šäka brādê. (Nov) Rukät je: së mu grẽ od rūkẽ säšto znâ napràvit. Niš mu, neböškōn, ne grẽ od rūkẽ. (NV) Ku mu pöje za r $r^{u} k^{u}$ õn. (Orb) Śtî je prevarìt śurcä, ali mu nî puôślo źa rukôn. Jednìman jûdiman griê śve od rukiê. (Pag) Ni griẽ sè za ruōkuõn. (Paz) Svë mu grè od rukè. (Pre) Išlo mu je za rukọnn i obogãti se je. Ništa mu ne grẹ̃ od rukẹ kako da ga je kộ ükle. (PiZ) Vèro sän kuntênta, grêdu mi te kröštule od rukê. (Rak) Ne grẽ mi dèlo od rukẽ. (Senj) Niš mi ne gre za rukun, ko da me j' niki zaštrigal. Krivili su železo za ogradu, ma ni njin to baš hodilo od ruke. (ŠiK) Ne grẽ non od rũki. (Vis) * pũóc za rūokũon (Bolj) pọćc za rukọn (Dra) ne grẽ mi za rūkôn (Hva) grẽ mu od rukê (Kon) hodit od rūke (Mrk) pố za rukûn, hodìt od rūkì (Omi) kõmu rẽ za rukũ (Orl) grê mu o' rúkē (Spl) puôć za rukuôn, griẽ mu od rukiê (Vrb)

grozit se z rukun komu prijetiti komu, htjeti udariti koga Grozĩl mu se j' z rūkũn. (NV)

hoće se (puno) ruk gdje potrebno je mnogo radne snage Tộ je vềliki posôl $i$ tộte se höće rũk. Tộte se höće püno rũk. (PiZ) Vèliko je odörina tõti se höće rûk. (Vis)

hodit od ruke do ruke mijenjati vlasnika (korisnika) * hodit od rukiê do rukiê $(\mathrm{Vrb})$

imat ča u ruka imati kakav dokaz, biti siguran u što Nẽma ûn nïš u rukâ, pa käko će ga tûžit? (Kon)

imat čiste ruke biti pošten (čestit, ispravan), pošteno raditi (postupati) Bùdi sìguran, ôn ìma čiste rûke. (Rak) * ìmat čiste rûke (Kon) imêt čìste rûke (Mrk) imät čiste rûke (Vrb) 
imat dobru ruku 1. vrlo lijepo (vješto) raditi, biti vrlo vješt u radu /koji se obavlja rukama/ Nâjbôje brĩči Pèrê, ìmā döbrū rûku. (Bla) 2. imati lijep rukopis Imaš dobru ruku, moreš povuć prostoručno dugu ravnu rigu. (ŠiK) * imìt lîpu rûku (Omi)

imat dritu ruku biti precizan u gađanju Za dohicîvanje je trîbe imët drìtu rûku. (Mrk) U Bärbanu su tëkli na prstênac, a uvî ča je zadìja, ìma näpro drìtu rûku. (Rak)

imat dvi live ruke nespretno obavljati posao, biti nespretan (nevješt) /u radu koji se obavlja rukama/ İmā dvî lĩvēe (rûki). (NV) Ma čâ ìmaš dvî lîve rûke?! Svë ti päda, käko da ìmaš dvî lîve rûke. (Rak)

imat gole ruke biti siromašan *imät göle rûke $(\mathrm{Vrb})$

imat kruh u rukami (rukan) biti kvalificiran za rad; biti financijski samostalan Dïca ìmaju krüh u rukämi, žive dôbro. (Rak) Näša dĩca ìmaju krüh rukän; danäs nas nĩsu potrïbni. (Med)

imat krvove ruke biti odgovoran za čiju nesreću (smrt, ranjavanje) * imät kãrvove/karvõve rûke (Vrb)

imet libar va rukah učiti; čitati Ne spàmetin se kadà son zädnji pût jimê lïbar va rukäh. (Lab)

imat pri ruki koga ča imati u blizini koga što Nĩ imäja prì rūkì kajĩ̌ pa je kröz pašajìce provūkà špâg. (Bib) Milikerc je vavik pri ruki, ako nestane letrike. Blaženi moj pašo, vavik mi je pri ruki. (ŠiK) * ìmat pri rûki (Kon)

imat pune ruke posla (dela) imati mnogo posla, biti vrlo zaposlen (zauzet), morati mnogo raditi Istûc mi, mölin te, tô plakèti(h) cükara u mortôr, püne su mi rûke poslä! (Hva) Nêkada je štramacẽr imẽl püne rûki dëla. (Kas) Vrẽdnā ženä, vävīk ìmā pùni rüki poslä. (NV) U zädnje vrîme ìman pûne rûke pôsla. (Rak) İman pùne rûke poslà već dvî nedìlje. (Senj) * imäti pùne rûke poslà (Bib) jemät punè rûke pôsla (Dra) ìmat pùne rûke pôsla (Kon) püne rûke dèla (Mrk) imät püne rûke pösla (Vrb)

imat ruku za ča uspijevati $u$ čemu, imati uspjeha $u$ čemu /za radnje koje se obavljaju rukama/ İmā rûku za rôžice, vìdēj käko njōj lêpo kānpanëlice rāstû! (Kas)

imat slobodne (odrišene) ruke biti slobodan u svom djelovanju, imati odobrenje za slobodno djelovanje Imëlā j pöli njegà slöbodne rûki. (Cri) Nekä činĩ kakò znô, ìmo odrĩšene rûke. (Dra) Čä će ti rëći da si u tì kolôr obilìja kužînu? Mi je rëkla da ìman slöbodne rûke, sàmo da büde lîpo. (Med) * imät odrĩ̌sene rûke (Hva)

imat šporke ruke biti nepošten (nečastan), nepošteno raditi; biti sklon krađi, krasti * imät špuõrke rûke (Vrb)

imat tešku ruku imati jak udarac Imäla je têšku rûku, dìcu je nàpro bolìlo kad bi ih bïla pljësnula. (Rak)* imäti téšku rûku (Bib) imët tëšku rûku (Mrk) ìmat tẽšku rûku (Kon) tiẽške je rukiê (Vrb) 
imat $\mathbf{u}$ rukah $\mathbf{i}$ škare $\mathbf{i}$ sukno imati potpunu slobodu odlučivanja İma $u$ rukäh i škäre i sūknö. (Mrk) * imät u rukäma i nöžice i sūknö (Bla)

imat vezane ruke imati ograničene mogućnosti djelovanja (odlučivanja) Ti je posudija šôlde i säda ìmaš vêzane rûke dok mu ne vr̂neš dûg. (Med) Ne môren nìs, rûke su mi vêžene. (Rak) * imët vezane rûke (Mrk)

imat zlatne (smodne, vredne) ruke vrlo lijepo (vješto) raditi, biti vrlo vješt u radu /koji se obavlja rukama/ İmo zlõtne rûke: čâ očìma vìdi, tô rukãmi učinĩ. (Bru) Mâlì ìmā zlãtnē rûki. (Cri) Mojä ženä šije za svë nõs, ìmo zlõtne rûke. (Dra) İmā zlâtne rûke, së ùmī $i z a$ së jū j vöja. (Gro) Svi misćerì je znua, imi je zluatne ruke. (Ist) Nevìsta od Rine ìma zlâtne rûke za čà ćêš, ko'š u küći, ko'š vàn kùcée. (Med) Imâl je nâš otâc smôdne rûke. Čă je vìdil, otô je i načinîl. (Nov) Ovâ dëlavica ìmā vrēdnë rûki. (Kas) Tvôj mûž ìma zlôtne rûki, va së se käpi i së znô storìt. (Lab) Uõn ìma zlãtne ruôke, së čâ rãbi ukuôli kùće uõn znâ storìt. (Paz) Vèruj ti mèni, ôna ìma zlâtne rûke. (Rak) * imäti zlātnë rûke (Bib) imät zlotne rûke (Hva) imät zlõtne rûke (Vrb)

imati arat u svojin rukah izučiti zanat, zaposliti se Säd ìma àrat u svojìn rukäh, je pöčeja dëlati u Üljaniku. (Rak)

imit dege ruki biti sklon krađi * imìt dège rûki (Omi)

imit srićnu ruku imati sreće (uspjeha), uspijevati * imìt srìćnu rûku (Omi)

ispod ruke [kupit, prodat, nabavit] neizravno, preko preprodavača (posrednika) [kupiti, prodati itd.] Cikulâde smo kupoväli spod rūkê. Nî se tô smëlo va butîgi prodāvät, sâmo spod rūkê. (Gro) Tû vëštu san kūpìla ispod rukẹ. (PiZ) Ispôd rukẽ ću nabävit. (Senj) * isspod rūkẽ (Bla) ìspod rūkè (Bib) kūpìt ispod rukẹ (Dra) akvištät spod rūke (Mrk) spod rūkì (Omi) ìspod rukiê kūpìt (Vrb)

isti iz ruke komu pitomo se ponašati, biti pokoran komu * isti kômen iz rūkè (Bib)

iz ruke u ruku od jednoga do drugoga * iz rūkë ù ruku (Bib) iz rûke ü ruku (Kon) z rûki v rûku (Omi) iz rukiê ù ruku (Vrb)

izmaknut se komu iz ruk propustiti, ne dobiti što * izmäknut se kồmu iz rûk (Kon)

judi ol naši ruki ljudi težačkoga staleža Reśpèt se iziskùje i ol jūdîh nãśi rūkì. (Vis)

kaj $<$ s $>$ rukon $<$ da $>$ je $k i$ uzel (odnija) $\check{c} a$ brzo je izliječeno što, brzo će se izliječiti što, nema više bolesti, više ništa ne boli koga Ovä zädnja medežîna mu je kài s rukôn üzela dolõre, u dvà dâna. (Med) $O^{\prime}$ kä' se namäza bazalmânun, kồ da mu je nëko reumu rukũn ödnija. (Mur) * odníti käj rūkôn (Bib) kồnda je rukôn odnèslo (Kon) ko/kakồ rukuôn odnešenô (Vrb)

križat se $\mathbf{z}$ livon $<\mathbf{i} \mathbf{z}$ desnon $>$ rukon jako se čuditi čemu, ne moći vjerovati Z lẽou rukũ san se kriżãal na te bedastõći. (Bel) Ne krĩzāaj se z līoûn rukûn! (Gro) Kad su skùpa döšli, bäba se krîžala z lîvon rukôn. (Rak) Käd je to vìdija, 
se je pöčeja krīžàti i z lîvon i z dêsnon rukôn. (Rov) * prekrīžìt se z lîvon rūkôn (Mrk) prikrstìt se lĩvon rūkõn (Bla)

latit $\mathbf{v}$ ruke početi što raditi $K^{u} \hat{o}$ dẽlo reš v rûke lãtit? (Sus)

lavurat priko ruke površno, nemarno raditi * lavurät priko rukẹ (Dra)

libar je komu u rukah uči tko; čita tko Svè je znâl jèrbo mu je šêmpre lîbar bîl u rukâh. (Nov)

liva ruka, desni žep krađa, džeparenje Svì znâmo da je ôn liva rûka, dèsni žêp. (Rak)

mahnut (odmahnut) rukon ignorirati što, ne mariti za što Tulìko pûtih san mu rêkla da su ga onì na kârte opeljûšili, a ôn bi sàmo mahnûl rūkôn i pobìgal. (Nov) Ni til slüšat, sàmo je odmahnũl rukõn. (Senj) * odmānìti rūkồn (Bib) odmânut rukôn (Kon) odmāhnüt z rūkôn (Mrk)

mašuć rukamin besposleno, ne radeći ništa Lîpo ti ôn po cêli dân grê mäšuć rukämin, ma šêmpre šôldi pîta. (Nov) Ködasi dôśaz Tarmêrke, mâśućin rukämin. (Ist)

mećat ruke na koga tući (udarati) koga/šakama/ Sömo nemôj rûke mećât ni na drugu... ni na trèću, perke bi za to iśal in galêra. (Vis)

moru dati jedan drugon ruku isti su, slični po karakteru, ponašanju /ob. negativno/ Môru däti jedãn drügon rûku. (Bib)

moru se uhitit za ruke isti su, slični po karakteru, ponašanju /ob. negativno/ Mồu se uhìtit za rûke. (Mrk)

muška ruka 1. strogost /ob. u odgoju/ Sin njoj je raspüšćen, ne môre vladàti š njìn er je odgöjen prez müške rukè. (Med) Ne möre onä sâma dič̀inu stävit na prâvi pût. Fäli totè muškâ rūkä. (Nov) 2. spretnost (vještina) u obavljanju popravaka u kući /osobito u tzv. muškim poslovima/ Vìd se da tôj küći fâlī müškā rūkä. (Gro) Tu se vìdi da je müška rũka. Sve je lîpo regulãno u kùći i kortîvi. (Med) Za otô poprävit trîba muškâ rūkà! (Nov) Se vîdi da je u tôj böški bîla müška rûka. (Rak) * müškā rūkà (Cri) müška rūkä (Mrk) 3. fizička snaga * müška rūkà (Bib) muškô rūkä (Hva)

na brzu ruku brzo, na brzinu, nemarno, površno $\mathrm{Na}$ br̀zu rûku posũdī, a onda otêže vrnüt. (Kas)

na desnu ruku zdesna, s desne strane Njiẽjna küća prĩde na diẽsno ruôko od ${ }^{\circ}$ Semenïšća. (Paz) Ûn živô kod sûda nûnde na dèsnu rûku. (Riv) * na dèsnu rûku (Bib) na prâvū rûku (Omi)

na dofat ruke je komu ča vrlo (posve) blizu je komu što, na neznatnoj udaljenosti je što Batìc mū j' bîl na dõfat rūkẽ. (NV)

na laku ruku bez truda (napora), olako, jednostavno Svè mu je dòšlo na läku rûku i svè je na läko špendâ. (Med) Ta kredit ne möreš ziẽt takô na lähko ruôko, muôraš dobrồ razmìslit. (Paz) 
na livu ruku slijeva, s lijeve strane İza onègā kantūnà prôa kùća na lĩvū rûku. (Bla) Âjde nâprid po ünda na lîvu rûku. (Riv) * naläziti se na lĩvu rûku (Bib) na lî̀u rûku (Omi) na lĩoū rûku (Paz)

na prste (naprste) jene ruke moći zbrojiti (nabrojit) koga, ča veoma je malo koga, čega, ima u maloj količini koga, čega Mälo je ljûdi bilo na mäši, su se mögli zbrojìti na pr̀ste jenê rukê. (Rak) Napr̀ste jene rūkê biš ih moga nabrojît. (Mrk)

na ruku je komu 1. (ča) prikladno je komu što, odgovara komu što Nĩ mi nã ruku lavurät na ovù bôndu. (Hva) Nĩ mi nä ruku bäcat nädesno. (Kon) Nije mi oni vìto nà ruku, jâko je dèzbānde, pa malo tamo idem. (Kun) Kad ${ }^{\circ}$ buôden šã zduôlon, ću poglèdat za armaruône va butiêge od ${ }^{\circ}$ mobîlije, tr će mi bìt jüšto na ruôko. (Paz) * bìt nä rūku (Omi) 2. (ki) na usluzi je komu tko, spreman je pomoći tko komu, od pomoći je tko komu Vãvek mi je bîl na rûku, kada gôt je mõgal. (Bel) Onà je dobrä sūsëda, vàvēk je säkēmu nä rūku. (Kas)

naruku je komu 1. (ča) prikladno je komu što, odgovara komu što Si je primìstija bliže lîbre da mu büdu näruku. (Med) Nî mi narûku pasät odonüda. Së mu grê narûku. (Mrk) Däj tî mëni onâj vìtal u Câski, a jâ ću tëbi onû njìvicu na Blâtnici kâ je tëbi näruku. (Nov) Ovồ mi je ọde svë nãruku. (PiZ) Niš mu nì näruku. (Pre) Säd mi je näruku dôjti poli tëbe. (Rak) 2. (ki) na usluzi je komu tko, spreman je pomoći tko komu, od pomoći je tko komu Niki nîma böljega kunjâda, vàvik mi je näruku. (Nov) Bîl mi je näruku. (Uni)

nenaruku je komu ča nije prikladno komu što, ne odgovora komu što Jušto mi je nenarûku pasät odonüda, dälje mi je. (Mrk)

na svoju ruku 1) čudan, neobičan, nepredvidiv, poseban Näš je susëd pàmetān, ali mälō j na svojù rûku. (Cri) Õn ti je na svojü rûku $i$ za svõj žêp. (Kas) Ũn je na svôju rûku. (Kon) Govôri bäba da je tetà bîla na svojü rûku. (Nov) Uõn ti je mälo na sojô ruôko, ma stëši storĩ së čâ zäme va ruôke. (Paz) Š njồn se krščàn niš ne möre dogovôriti, učìnjena je na svöju rûku (fõzu). (Rak) * bìti čovik na svojû rûku (Bib) bìt na svojù rûku (Dra) bìt na svojü rûku (Hva) bìt na svojü rûku (Omi) 2) samostalno, samoinicijativno, po svojoj volji (odluci, inicijativi) Nîs te nïš pìtâl, tî si së svojevõjno, nä svoju rûku, störīl. (Gro) Vàvēk su dëlali na svojù rûku. (Kas) Svè je učinìja na svõju rûku prez da je kẽga nïš pitä. (Med) Učinîl je ôn svë na svojü rûku. (Nov) Iskrcâli su ga na krầj jer je sve činî na svöju rûku, nïkoga me slüša. (Riv) * učinìti (rādìti) na svojü rûku (Bib) rabötot na svojù rûku (Dra) naprävit na svôju rûku (Kon) na svojü rûku (Vrb)

ne bi tko jil (ze) ni orah iz ruke komu osjeća tko odbojnost (gađenje) prema komu Sve jon je hàlāvo pò kući, ne bi jon ni òraha iz rúke jìla. (Kun) Onoj šporkaćôni nebih zê ni orìh z rûk (Mrk) 
ne fata se delo (posal) ruk komu neradnik je tko Nèdelu se dèlo ne fâtā rũk. Levẽnti se posãl rũk ne fâta. (NV)

ne podaje se ruk komu ča ne uspijeva komu što, nije sposoban učiniti tko što, nema uspjeha tko u čemu Ne fâtāj se poslä, ki ti se rũk (rukãn) ne podājè. (NV) Pustì če ti ne podâje rûk! (Omi)

ni u rukah ni u nogah uopće, nikako Nî snāgê vìše ni u rukâh ni u nogâh. (Nov)

nisu ni svi prsti na ruki jednaki ljudi su različiti Jẽna mäter rôdi dvà ditèta pa nĩsu jëdnaki käko ča nĩsu ni svï pr̀sti na rũki jëdnaki. (Med) Ni svì pãrsti na rūcì nīsü ìsti. (Vrb)

nosit $\operatorname{kog} a$ na palmu od ruki poštivati, cijeniti neobično mnogo koga * nosìt kogà na pâlmu od rūkì (Omi)

nositi na rukah koga previše činiti za koga, ugađati komu u svemu Marĩno je njû nosìja na rukäh.(Rak)

oblatit ruki s čin sudjelovati u kakvu nečasnu poslu, činiti što nečasno Nêce ti õn z dëlōn rûki oblätit. (Kas) * šporkäti rûke (Bib) šporkät rûke (Mrk)

od (iz) druge ruke [kupit] rabljeno, već upotrijebljeno Kupĩ san ãuto, ma do drüge rukì, kî će mi dät sóldi za nõvoga? (Bel) Môj je sin kûpi vitùro ot drüge rukì. (Lab) Smo kupïli âuto od drüge rukë, kako nồo. (Med) Kūpïli smo kaïć od drüge rūkiê, a kakuôv je morebìti da jei od trëće. (Riv) San mïsli kupìt jëno vetüro od ${ }^{\circ}$ drüge ruôke, ma pr̀vo nëgo jo kûpin, ću jo peljät puli

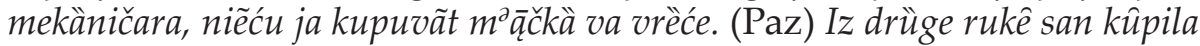
vetrĩnu. (Rak) * iz drüge rūkë (Bib) od drüge rūke (Mrk) od drügè rūkì (Omi) iz drüge, trëće rukiê (Vrb)

od isti (sridnji, gospolski, težoški) ruki koji pripada istom (srednjem, gospodskom, težačkom) staležu Prõvo je ìstina, da se u nevöji glëdo prijatẽstvo, a otö govorêć obo prìjatejima od ìsti rūkì. U gospolskè küće i onë od srîdnji rūkì naprôvan je bôr. Śier Zanèto Bonasêra, jedôn ol gospolskì rūkì, intrōjè u jovèmu kako covìk od momènta. Kumpôre Śìmë, ol težóśki rūkì, modêrni covìk ôd svita. (Vis)

iz (od) prve ruke [zet, reć, čut] izravno, direktno, bez posrednika, iz sigurnog izvora Drügi äuto san jâ zêl od pr̀ve rūkê. (Nov) Iz pr̂ve rukê ti mören nišsto rëči. (Rak) Čũl san tô iz pròve rukẽ. (Senj) * iz pr̃ve rūkè (Bib) iz prìve rukê (Kon) iz parviê rukiê (doznät i sl.) (Vrb)

od ruk do ruk zajednički, složno Od rûk do rûk su dìzali i nosìli stîne. (Rak) od ruki je komu ki na usluzi je komu tko, spreman je pomoći tko komu, od pomoći je tko komu Nëka grẽ mälo pöli njegà, mõrda mu büde od rūkì. (Cri) okrvovit ruke biti odgovoran za čiju nesreću (smrt, ranjavanje) * okarvōvìt rûke (Vrb)

oprat izmeju ruk oprati rublje na brzinu, ručno * òprat izmejū rûk (Spl) 
oprat/prat <svoje > ruke $o d$ čega skinuti/skidati sa sebe odgovornost $z a$ što, ne smatrati se krivim za što Ja tämo nîs bïja i pèren svõje rûke od tìh stvârih. (Med) Ja ču upräti rûke od svêga tèga. (Rak) * pràt rûke (Kon) prät rûke (Mrk) prät rûke (Vrb) prât rûke (Vis)

pasat kroz ruke oprati rublje na brzinu, ručno * pasàt kròz rūke (Bla)

plaćat na ruke davati novac izravno (bez posrednika) Gospodâr ga plấa na rûke. (Med) * dàt nä ruke (Kon) dàt (dobìt, prìmìt) nã ruke (Vrb)

platit ruke platiti rad Za rûke san mälo plâti. (Mrk)

pljuknut (huknut) $\mathbf{u}$ ruke ozbiljno se prihvatiti posla, prionuti uz posao * pljüknut (hūknüt) u rûke (Mrk) pjünūt v rûki (Omi)

poć ća prazneh ruk ne dobiti ništa na odlasku Unä te sìgurno niẽće puštìt da griěš ćà prãzneh ruõk, väjk će ti dät popütnico. (Paz)

pošlo je iz prve ruke komu ča uspjelo je komu što iz prvoga pokušaja San imä strâh da néću finuti dêlo, ma vêro mi je pöšlo lîpo iz proe rukê. (Med)

potriba je ruk $z a \check{c} a$ potrebno je mnogo radne snage $z a$ što Jübicinimu öcu kad je bilo potrîba rûk za üpoje... (Vis)

prat (potezat, šit itd.) na ruke ča ručno prati (potezati, šiti itd.) što Pèrlìn se rābîl dokla nî bîlo mäkīn za prät, döklī sē j prâlo nä rūke. Štramäci su se nä rūke prošĩuäli. (Gro) Prî se svë prãlo nã ruke; vëće rûke nëgo materijôl! (Hva) Sâmo je to činila i ù dva dana ga je nà ruke spléla. Ù ratu se pàsta činila nà ruke, a sad je ima svake lipe sôrte. (Kun) Od potèzanja püne mrïže nä ruke rûke ti se šundräju! Nî privo rïbariman bîlo läko. (Nov) Cemo perievät na ruôki? (Orb) Jöš ka sen ja imẽla ovïh mojîh dẽc, jä sen nin šilla svề na rûki. (Orl) To blûzo ću uprät na ruôke ač me je strâh da ne pûšti koluôr. Jedanpũt se je nosìlo röbo žnjîdarice šit, a dôsta tëga se je šilo na ruôke. Beâte mäkine za mũs, kad ${ }^{\circ}$ se je na ruôke mũzlo kràve je bîlo čùda dèla säki d’ân za pomũs kräve. (Paz) To dr̀vo je mäša tvř́do pa ga je têško prosuṛdlat nä ruke. (Pre) Maštel pun robe triba oprat na ruke. (ŠiK) * prät nä ruke (Kon) na rûke (Mrk)

prat (virati) naruke ča ručno prati (dizati) što Va Marsëju uvik vira, majna; sve smo murali viräti näruke. (Ist) Màt je svü röbu prâla näruke. Jôs tetä držî konöbi maštêl čà se je prrvo va njemù röbu prâlo näruke. (Nov)

pri ruki je komu 1. (ki) na usluzi je komu tko, spreman je pomoći tko komu, od pomoći je tko komu Ũn mi je väjk pri rûki. (Kon) * nṍc se pri rūcī (Dra) bìt pri rūcì (Vrb) 2. (ča) u blizini je što, dostupno je što * bìt pri rūcì (Vrb)

prijet (uzet) libar v ruki učiti; čitati Pòvazdân si po vanü, kadà ćeš prijẽt lîbar v rûki? (Bel) Ostãv se igrì i igrõnjo i uzmì lîbar ü ruke. (Vis)

prikriženih ruk [sidit, gledot] besposleno [sjediti, gledati], ne radeći ništa * sìdìt (glëdot) prikrǐženih rûk (Vrb)

prit $\mathbf{v}$ ruki komu potući se /šakama/ Kadà tadà prĩt ćeš tî menè v rûki! (Bel) * prît v rûki (komü) (Omi) 
propušćat kroz ruke koga tući (udarati) koga/šakama/ * propüšćat kòga kröz ruke (Kon)

pružat ruke posezati (rukama) za čim tuđim $\hat{A}$, ona znô dìgod prūźât rûke. (Vis)

pružit ruku komu pomoći komu, ponuditi pomoć (prijateljstvo, pomirenje) komu Glèdaj se braton pomīrìt! Prüži mu rûku, pa ćeš vìdit òce je prihvätit. (Nov) * prüžiti kômen rûku (Bib) prüžit rûku kömu (Kon) prüžit rûku (Vrb) puno ruk mnogo radne snage Püno je rûk pa pośâl griê bèrź́o. (Pag)

pušćat iz ruke ča držati veoma čvrsto što Daržì tồ jüski i ne pũšćoj ìz ruke! (Hva)

puštiti iz ruk koga, ča $\mathbf{1}$. okrenuti se od koga čega, napustiti koga što Puštìla je iz rûk svü famëju. (Rak) * püšćat iz rûk (Kon) 2. izgubiti vlast (kontrolu) nad kim, nad čim, propustiti priliku da se što dobije * puštìt z rûk (Mrk) pustìt z rûk (Omi)

ruka Božja kazna Rūkì Böžijoj nìko ne môre izmaknìti. Dostìgla ga rūkà Božjâ. (Bib) * rūkä Böžja (Bla)

ruka ruku mije (pere) uzajamno se pomagati Rūkà rūkù mìje. (Bib) Rūkà rûku père. (Mrk) Rūkà rûku mïje. (PiZ) Ruka ruku mije, obraz obadvije. (ŠiK) Rūkà rûku mije. (Vrb)

ruka $t i$ se posvetila $<$ !> /odobravanje čijeg djela/ Rūkà ti se posvêtìla! (Bru) Rūkà mu se posvêtìla käd je ucinî tö za nôs! (Hva) Rūkä mu se posvệtìla! (PiZ) ruke su čiste čije pošten (čestit, ispravan) je tko, pošteno radi (postupa) tko Jà nîman nïc s tên špôrken dëlon i mojê so rûki cìste. (Lab) Mojê rûke su čîste. (Nov)

ruku na srce iskreno (otvoreno) govoreći, pravo da kažem, ako ćemo pravo, reći ću <pravu> istinu Rûku na sìce, nĩ njōj bìlö lähko. (Cri) Dâ ti se pijažâ mäja? - Rûku na sr̆ce, nè!! (Gro) Rûku nä srce, ûn nî krîv. (Kon) Vřži rûku na sìce i prìznaj da si žbaljä. (Med) Vr̀zi rûku na sr̀ce i povîdaj kakö je bîlo. (Nov) Rûku na sìce, morân ti nî̌sto rëči. Rûku na sr̀̀ce, bölje da njin dâš šõlde nègo čâ drügo. (Rak) * rûku nä srce (Bib) rûku nã sãrce (Hva) rûku na sìce (Mrk) rûku nã sarce (Vrb)

s prekriženimi rukami [udelat] ča besposleno [raditi] što, ne radeći ništa $S$ prekrĩzenimi rukãmi nìs se ne mõre udẽlat! (Bel)

s rukan u žepu besposleno, ne radeći ništa Je glëda kãko jä dèlan. Da je ôn vëlika glãva? A je ôpra sästanak s rukàn u žẽeu. (Med)

skrstit ruki ne raditi ništa Nãjlagjē j skrstìt rûki i čêkat da Bôg pošăje. (Kas)

stavit (vrći, dat) ruku u oganj $<z a \operatorname{kog} a(d a \ldots)>$. jamčiti $\langle z a k o g a(d a \ldots .)>$., imati puno povjerenje $\langle u k o g a\rangle$, čvrsto vjerovati $\langle d a \ldots . .>$ Räje rûku v' ogànj stầit, nar zešnjĩn poslä jimêt. Za tô bin stävil rûku v' ogànj. (Bel) Ga poznâmo dõbro, nẽ bi ni jä vö̀ga rûku u òganj zâ nj. Nẽ bi za nìenoga vờga rûku u öganj. 
(Med) Jâ bi dâl rûku u ogânj da ôn otô nèdilo nî naprävil. (Nov) Stàvila bin rûku u öganj da je jüšto ôn ukrëja mrïžu $i$ špäg. (Rak) Räje stävit rûku v oggãnj nëgo z nëkēn poslà imët. (Ruk) * däti (mëkniti) rûku u vätru (Bib) dàt (mêtnut) rûku u vätru za kòga (Kon) stàvit rûku u òganj (Mrk)

stavit ruku na panj za koga jamčiti za koga, imati puno povjerenje $u$ koga, čvrsto vjerovati Stävila bin rûku na pãnj za njegà. (Cri)

stvorit rukamin ča biti vrlo vješt u radu /koji se obavlja rukama/ Brät rukämin stvôri svë čà zamìsli, a sesträ je vîše za drügi posâl. (Nov)

trljati ruke biti zadovoljan kakvim uspjehom * triljàti rûke (Bib) triljat rûke (Kon)

tuć z rokami aplaudirati, pljeskati $M a$ so tũkli z rokämi kad ${ }^{\circ}$ so unì finili kantàt. (Paz)

u Božjin rukan je ča neovisano je o ljudskoj volji što, prepušteno je božjoj volji što Svề je u Böžjin rukän. (Bib) U Böžjima je rukämi. (Kon) Sè je u Bôjžih rukäh. (Mrk)

u drugu ruku s druge strane, drukčije gledano, gledajući malo drukčije $U$ jednü rûku dobrö je ovãko, a u drügu rûku bîlo bi böje. (Hva) * u jednü rûku ... u drügu rûku (Vrb)

u jednu ruku s jedne strane, <gledajući> na jedan način Va jednù rûku dobrö da smo käšnjē prišlì. (Cri) Mìslela sān da nĩmā pràvoo, a va jednù rûku i ìmā. (Gro) U jednü rûku dobrö je ovãko, a u drügu rûku bîlo bi böje. (Hva) U ëdnu rûku je tô i döbro. (Kon) U ẽnu rûku ìmaš tì pràvo, mä ko dõbro glèdaš râbi razmìsliti. (Med) U jènu rûku ìmaš pràvo. (Rak)* u jenu rūku (Mrk) u jednü rûku ... u drügu rûku (Vrb)

u najbolju ruku u najboljemu slučaju, najviše, maksimalno * u nâjbölju rûku (Bib) u näjbolju rûku (Kon)

u najmanju ruku barem, ako ništa drugo, možda samo to Moglà tī j, va nãjmanjū rûku, pijät jūhê skühat, kad ti već nî otêla dìtë počūvät. (Gro) Danäs bi te cêkola u nôjmãnju rûku kancelarìja, ako në $i$ cãgod böjega. (Hva) U nàjmanju rûku tô je bëzobrazno. (Kon) * u nâjmänju rûku (Bib) u najmänju rûku (Mrk) u nôjmãnju rûku (Vrb)

u niku ruku na neki način, s jedne strane, donekle, do neke mjere $U$ niku rûku möže se rëć da je tãko. (Dra) U nïku rûku jöš je dobrồ i ispãlo! (Hva) *u nïku rûku (Bib) u nëku rûku (Kon) u nïku rûku (Vrb)

u ruke Božje na milost božju Èto sînko, ù ruke Böźje. (Vis) * ù rūke Böžje (Bla) u Böžje rûke (Kon) dät se v rûki Böžje (Omi) ù ruke Böžje (Vrb)

ucit se u ruke učiti se vještini ručnoga rada, krojenja i šivanja Hodìla se je ucìt ü ruke u śjeri Marìji. (Vis)

ufatit va ruki ča prihvatiti se kakva posla Doskonjâ ča ufàti và rūki. (NV) 
uzet $<$ stvar $>\mathbf{u}<$ svoje $>$ ruke odlučno preuzeti što, prihvatiti se čega, uzeti pod svoju vlast što, zavladati čime, pobrinuti se osobno za što Pökle je õn üzeja stvâr u svojê rûke. (Bib) Do säd se nî nìs vìdilo, ma od käd je ôn üzeja u svõje rûke, svề je pöšlo nãprid. (Med) Uõn je kapâc storìt ča god zäme va ruôke. (Paz) Nârod je ùzeja stvâr u svôje rûke. (Rak) * zêt u svôje rûke (Kon) zêt u svoje rüke (Mrk) vaziêst u svojê rûke (Vrb)

z golima rukami bez oružja (alata), nenaoružan, samo svojom snagom (spretnošću) Z gôlima rukämi se vìga na dìbljega prâsca ki mu je döša na pût. (Rak) * golin rukän (Bib)

z rukami i nogami svim snagama $Z$ rukämi i nogàmi jū $j$ zakālĩl. (NV) ${ }^{*} z$ rukämi i z nogàmi (Mrk) rukãmima i nogãmima (Vrb)

za prvu ruku za početak, za prvo vrijeme Bìt će nān za pr̀vū rûku dôsti. (Cri) Mâjstor nĩ döša, pa je õn po tõn nïšto prìckaja, valjâ če za pr̃ou rûku. (Bib) Èvo son ti dòni mãlo prôsa $i$ mišônce za parvü rûku. (Hva) Za pròvu rûku če nan bìti dôbra i tâ kämara. (Rak) Dici smo za pròu rûku dali fit, a za mobiliu neka sami misle. (ŠiK) * za pr̀̀u rûku (Kon) za pr̀̀u rüku (Mrk)

zet kruh z ruk postići što na tuđi račun * zet krüh z rûk (Mrk)

zet na lahku ruku ne pridavati čemu previše pažnje * zẽt na lähku rûku (Orl)

zet u ruke koga tući (udarati) koga /šakama/ Kad je jã zämen ù ruke, nẽ će ostät niš. (Senj)

zvan (vanka) ruke je komu ča daleko je komu što, na udaljenom je mjestu što Ne mögu pố tãmo lavuràt, tô mi je vônka rukê. (Hva) Bin prĩšla, ma tuô mi je prevëć $z v^{2}$ ạn ruôke. (Paz) * bìti vãn rūkë (Bib) vanka rūkẽ (Bla) bìt vôyka rukẹ (Dra) zvân rūke (Mrk) zvên rūkì (Omi) bìt vônka rukẹ (PiZ) vônka rũki (Vis) bìt vônka rukiê (Vrb)

zvanruke je komu ča daleko je komu što, na udaljenom je mjestu što Zvanrūkẽ je njìhova küća. (NV)

ženska ruka žena koja ima smisao za lijepo i red /osobito u tzv. ženskim poslovima/ Vìd̄̄ se da tôj küći fâli žẽnskā rūkà. (Gro) Küća je lîpo regulãna, se vïdi da je u küći žènska rũka. (Med) Otkakö se je oženîl, vìdi se da je u küći žênska rūkà. (Nov) Se vìdi da je u hïžu döšla žẽnska rûka. (Rak) * žênsko rūkä (Hva) žênska rūkä (Mrk) 
